\title{
Health Effects of Indoor Air Quality on Children and Young People
}

\author{
STEPHEN HOLGATE, ${ }^{*}$ JONATHAN GRIGG, HASAN ARSHAD, \\ NICOLA CARSLAW, PAUL CULLINAN, SANI DIMITROULOPOULOU, \\ ANNE GREENOUGH, MIKE HOLLAND, BENJAMIN JONES, PAUL LINDEN, \\ TIM SHARPE, ALAN SHORT, BRIONY TURNER, MARCELLA UCCI, \\ SOTIRIS VARDOULAKIS, HELEN STACEY AND LINDSEY HUNTER
}

\begin{abstract}
Air pollution is the environmental public health problem of our time. The United Nations Convention on the Rights of the Child sets out clear guidance to protecting the rights of children and young people, including a child's right to the best possible health (Article 24) and the right to a good standard of living. Unicef also consider that clean air is a right for all children. The UK Royal Medical Colleges vigorously advocate for a healthy environment at the population level and in local communities, especially where socio-economic circumstances limit the choice of where people can live, and which school children attend. Despite substantial progress in understanding outdoor air pollution, the potential risk to health, especially that of children and young people, from the indoor air has been largely overlooked, yet in modern times, the indoor environment has never been more important as lockdown with the Covi-19 virus pandemic has shown us. Here we provide an abridged version of the RCPCH/RCP Report The inside story: Health effects of indoor air quality on children and young people but without the section on recommendations. The full Report along with
\end{abstract}

${ }^{*}$ Corresponding author.

Issues in Environmental Science and Technology No. 50

Environmental Pollutant Exposures and Public Health

Edited by R.M. Harrison

(C) The Royal Society of Chemistry 2021

Published by the Royal Society of Chemistry, www.rsc.org 
recommendations, released on 28 January 2020, can be accessed at https://www.rcpch.ac.uk/resources/inside-story-health-effects-indoorair-quality-children-young-people. While we recognise that some aspects of this commentary are UK specific, much of the content has wide implications.

\section{Changes to the Indoor Environment}

There are several well-established health risks from indoor pollution that include the following.

(1) Carbon monoxide can be released by faulty gas appliances. It is a deadly indoor pollutant, for which there are tight regulations.

(2) Tobacco smoke is highly toxic and there are direct health effects when the smoke is inhaled (Box 1). Tobacco smoke is known to be one of the most important indoor air pollutants and its toxic effects have been captured or reviewed elsewhere. Less well-known is that tobacco smoke can be absorbed by surfaces in the home, and chemically react with other indoor pollutants - "third-hand tobacco smoke". 2

(3) Radon is a radioactive gas found in parts of the UK. If a building is under-ventilated, dangerous levels of radon can build up indoors. It has been shown to greatly increase the risk of lung cancer, especially in tobacco smokers. ${ }^{3}$

(4) Asbestos was widely used in building materials. It was banned after being found to cause serious health conditions (mesothelioma and asbestosis). Asbestos is still present in many buildings across the world but despite this, research interest seems to be declining. ${ }^{4}$

Box 1 Smoking.

Smoking is a significant source of pollutants indoors and will dominate exposure to air pollutants for smokers and their co-habitants.

Exposure to third-hand smoke (THS) is when chemicals emitted from smoking stick to and react with indoor surfaces. Nicotine can react in this way to form carcinogenic particulates. Higher PAH (particulate matter produced by burning) concentrations occur in houses with smoking. In non-smoking houses, emissions from cooking and fireplaces are the main sources of PAHs.

In Scotland, children's exposure to second-hand smoke was lower in households with smoking restrictions and where the mother felt confident enforcing the restrictions.

As e-cigarettes and vaping rise in popularity, there is little evidence about their impact on air quality. It is not known if there are adverse health effects for children exposed to the emissions. Until this evidence is available it would be sensible to take a precautionary approach and avoid exposing children to vaping and e-cigarettes indoors. 
Beyond these well-established hazards and risks, the evidence base linking health effects specifically to indoor sources of pollution is growing and developing.

These indoor sources of pollution are now closely regulated. However, since enacting these controls, there have been major changes in the indoor environment and to buildings. Rather than solid wood, furniture and flooring are now more likely to be made with a veneer glued to composite wood. Cotton or woollen carpets have been replaced by synthetic fibres, which are treated with stain repellents and flame-retardants. Feathers, wool and down once used as cushioning are routinely replaced by flame-retardant treated, synthetic foams. In the 1970s, the energy crisis changed the design and building of houses and public buildings. There was rightly a new emphasis on insulation and reduced ventilation to save energy costs. Energy efficiency is both economically and environmentally important, and there are important health benefits to warm, dry homes. However, buildings have become increasingly air-tight with little natural ventilation. Without adequate ventilation, and with new sources of pollutants indoors, health issues have been associated with poor air quality. Unfortunately, research has not kept pace with the changes to our indoor environment(s), and many products have been introduced with little or unknown effects on humans, especially in combination.

Poor air quality at home, in school, and in other enclosed environments can be the dominant way children are exposed to pollution. Indoor air quality depends on the building's location and characteristics, pollution levels outside, indoor pollution sources, and lifestyle factors (Figure 1). People can be exposed to high levels of indoor air pollution over a short period of time or to relatively low pollution levels over prolonged periods. Both acute and chronic exposures need to be considered indoors. Pollutants can become trapped and reach high levels in under-ventilated rooms. Children spend many hours a day in their homes and classrooms, so even low levels of pollution can contribute to accumulating exposure.

Most health studies have focused on outdoor air pollution. A comparatively small number of studies have been specifically designed to estimate air pollution exposure and associated health effects in the indoor environment. It is possible that the effects are different. There is some emerging evidence, for example, that indoor particulate matter could be more harmful than equivalent levels outdoors. A study from Germany suggested that particulate matter with diameter $<10 \mu \mathrm{m}\left(\mathrm{PM}_{10}\right)$ collected in classrooms induced inflammatory and allergenic reactions, and accelerated blood coagulation, more than outdoor $\mathrm{PM}_{10}$ on an equal weight basis. ${ }^{5}$

\subsection{Measuring Exposure to Pollutants}

Exposure to indoor air pollution has been linked to health effects in children using a variety of methods. A common approach is to use standardised 


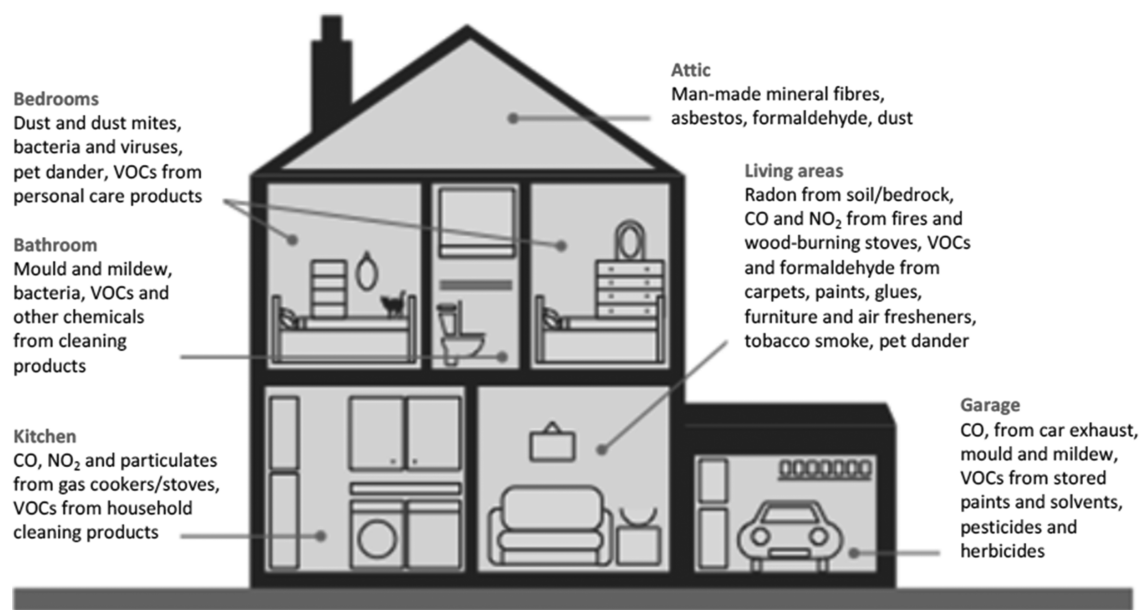

Sources and types of indoor pollution encountered in homes. VOCs = volatile organic compounds. Please note that these lists are not exhaustive and that the actual pollutants present, and their amounts, will vary from household to household.

Figure 1 An overview of sources of indoor pollutants in a home. Reproduced with permission from the Royal College of Physicians.

questionnaires. These collect data on the home conditions, development of disease, variation in symptoms, and measures for quality of life. Studies often use questionnaires to assess damp and mould in the home. These 'selfreported' levels are used instead of directly measuring the humidity and levels of mould spores in the air or dust. Health assessments including physical examination, lung function testing, evidence of allergic sensitisation, and imaging are also used. Dust from rooms or mattresses is often collected to test for allergens, but levels in dust only approximate the allergens an individual is exposed to. Personal samplers, worn by an individual, can give a more accurate exposure assessment but these can be a burden for research participants. Sensors in different rooms and time-activity diaries have also been used to model individual exposures to a variety of air pollutants. $^{6}$

To measure pollution accurately, capturing changes throughout the day and in response to different activities, requires sensitive and complex monitoring equipment. One less complex method is the use of passive samplers. These are tubes with filters and materials to absorb pollutants. Once removed and analysed, passive samplers provide a total or average level of the pollutant. However, they cannot record how levels vary over time, and only provide a measure of average exposure over the entire period. Some studies rely on the use of proxy values to estimate exposure to pollution. For instance, $\mathrm{CO}_{2}$ is often used as an indication of ventilation (instead of measuring ventilation air flow rates directly). Total volatile organic compounds (TVOCs) is also used as a proxy for VOCs but does not distinguish between different VOCs. ${ }^{7}$ 


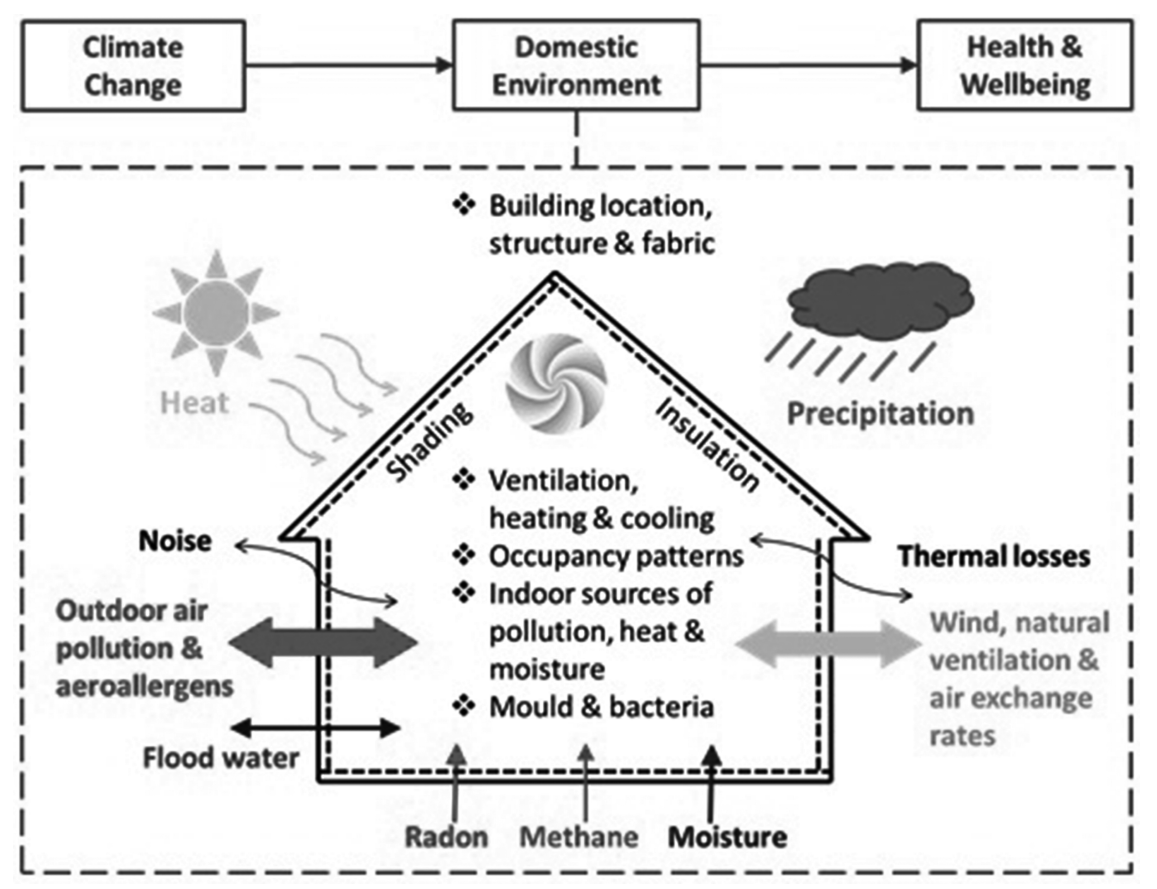

Figure 2 Drivers of indoor air quality in homes and schools.

Reproduced from ref. 14 with permission from Elsevier.

The difficulty of measuring pollutants means that the number of individuals or homes in studies tends to be low. This reduces the power of the studies to detect health effects from observations made in real indoor environments, and our ability to draw firm conclusions from the results. Despite the challenges, several important and good-quality indoor research projects have been undertaken in the UK and overseas.

\subsection{Factors Affecting Exposure to Pollution}

Exposure to pollutants is determined by the presence of indoor and outdoor sources, and the air exchange between the indoor and outdoor environment. However, various interconnected factors directly or indirectly affect these exposures, including climate change (Figure 2).

\subsubsection{Outdoor Factors}

\subsubsection{Urban planning}

Urban layout impacts air pollution levels. Buildings and industry change ground-level emissions and the ease with which pollution can disperse. Designs such as 'street canyons', where a space is flanked by buildings, trap air pollutants. Simple changes, and careful planning of new buildings, can be used to create openings and vary the heights of buildings. These features 


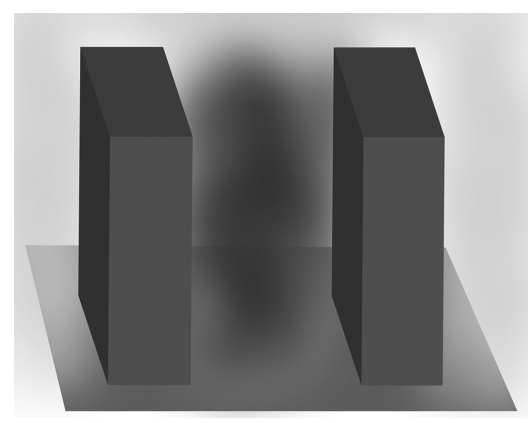

Figure 3 A 'street canyon' between buildings which can result in a build-up of air pollutants.

Reproduced with permission from RCPCH.

help pollution to disperse more easily. The building shape, size and orientation in relation to other buildings will also affect the level of pollution. Tall buildings, courtyards and enclosed spaces trap pollution ${ }^{8}$ (Figure 3). The location of pollution sources, such as busy junctions or power-plants, can be designed and located in ways that improve the local environment.

\subsubsection{Weather and Seasons}

Weather conditions also influence both outdoor and indoor levels of pollution. The wind speed and direction will change how pollution disperses or accumulates in an area. Wind also changes the rate of ventilation in buildings; ${ }^{9}$ even for buildings with mechanical ventilation systems. Outdoor temperature has a similar effect to wind because of the movement, as hot air rises and cooler air falls. This effect is sometimes referred to as 'buoyancydriven' motion. It can be especially influential in built-up areas, where urban 'heat islands' become significantly warmer than surrounding areas. ${ }^{10}$

The seasons also influence levels of pollution. There are typically higher indoor $\mathrm{NO}_{2}$ and $\mathrm{PM}_{2.5}$ concentrations in winter as a consequence of increased use of gas appliances, solid fuel heating, candles, and reduced ventilation in houses. ${ }^{11}$ Weekly measurements in urban parts of Hertfordshire and north London showed that outdoor $\mathrm{NO}_{2}$ concentrations were significantly higher than indoor concentrations in winter. ${ }^{12}$ There were no significant differences in indoor and outdoor levels in summer.

1.2.2 Building Characteristics. The design, ventilation and size of the building can have a large effect on the concentration of indoor air pollutants. Higher PM concentrations are typically found in houses with sources of smoke or burning, or with open plan kitchens. There is an increasing trend towards smaller homes with open plan designs. In the presence of indoor pollution sources, this may result in increased exposure to particulate matter. ${ }^{13}$ Homes are also becoming more airtight, to reduce thermal losses and improve energy efficiency and reduce the 
use of fossil fuels inked to climate change. However, these good intentions are inadvertently impacting upon health from reduced ventilation and worsening indoor air quality. ${ }^{14}$ There must be performance-based design of buildings that prioritises solutions that improve energy efficiency, protects the health and well-being of people inside, and reduces carbon emissions.

\subsubsection{Construction Materials}

Different chemicals can be emitted from the materials used to construct buildings and from their ensuing decay. These are materials such as insulation, natural wood and wooden composites, flooring, wall papers, solventbased varnishes and adhesives. Materials used to decorate, preserve, and seal, such as paints, caulks, adhesives, varnishes, waxes, and polishes, are all long-term sources of VOCs or formaldehyde and are often highly reactive with other pollutants. The emissions from building materials can reduce the indoor air quality of new homes and following renovations to older properties. Formaldehyde persisted in new homes longer than other VOCs. ${ }^{15}$ Levels of formaldehyde are higher in new homes, ${ }^{16,17}$ in apartments renovated in the past two years, and in homes constructed or furnished with wood. $^{18,19}$

Cables and pipes for electricity, water (drinking and waste), and heating are often contained within the building fabric. It is sometimes a design choice to expose them, in which case they should be considered as a source of indoor air pollution. Copper water and heating pipes have been replaced by PVC in many new and renovated buildings. PVC pipes release semivolatile organic compounds (SVOCs) that could migrate into indoor environments over time. ${ }^{20}$ Electrical, audio-visual, communications, and computing cables are often insulated with PVC. The covering contains plasticisers to make it flexible and releases SVOCs.

A common list of substances and their emission limits (EU-LCI values) has recently been published by the European Commission. ${ }^{21}$ This will enable comparison of the emissions from building products, helping to protect and inform people across Europe. It could be used to develop UK materials labelling schemes, which currently only exists for paints.

\subsubsection{Furnishings}

Furnishing includes all the furniture, fittings, floorings, curtains, and other accessories in the building. Many furnishing items and materials are a known source of chemicals and VOCs. The emission of pollutants can be increased by regular treatments such as polishing, or by the presence of ozone. $^{22}$ Public Health England conducted a systematic review of VOCs present in homes, focusing on those known to negatively affect health. This review was used to develop guideline limits for short- and long-term exposures for selected VOCs. ${ }^{23}$ 
Fabrics and some furnishings are treated with chemical flame retardants. These tend not to be emitted into the air but are long-lasting and found in house dust which, when inhaled or ingested are linked to long-term health effects. ${ }^{24}$ In the UK, the Furniture and Furnishings (Fire Safety) Regulations govern the required fire resistance for upholstered furniture and furnishings for homes. This includes a 'match test' of resistance to an open flame, which has been associated with a higher use of flame retardants than methods to test the product as a whole. Britain and Ireland are the only countries in the EU that require the 'match test', although in Britain this is under-review with proposed changes ${ }^{25}$ to the regulations published in 2019.

\subsubsection{Ventilation}

Ventilation is used to replace the air, which helps to stop pollutants accumulating. This can be achieved naturally with vents, doors and windows, by a mechanical ventilation system, or by hybrid systems that combine the two. Mechanical systems use fans to send air in and out of buildings, usually through a network of ducts between rooms. By bringing outdoor air inside, indoor air contains both particles that have infiltrated from outdoors and particles that have been generated indoors. ${ }^{26}$ Mechanical systems often include filters, which are designed to reduce the maintenance requirements for the equipment.

Ventilation ducts can be a source of particles, odours, bacteria, and viruses. Settled dust in ducts can be sent back into the air when fans are switched on. Cleaning the ducts generally leads to a reduction in exposure risks to pollutants. However, it can also cause a reduction in short-term air quality because the cleaning also raises settled dust. Biocides, sealants, and encapsulants are sometimes used to treat dirty ducts; the health risks from these are often unknown.

\subsubsection{Air Filters and Purifying Devices}

It is increasingly possible to clean outdoor air - either with filters in a ventilation system or with a standalone air purifier. Indoor air cleaning uses several different technologies including thermal or photocatalytic oxidation, adsorption, filtration (of particles), ultraviolet germicidal irradiation, ion generation, and electrostatic precipitation. ${ }^{27}$ The cleaners often target biological pathogens, with applications including hospital disinfection, odour removal, and removal of air pollutants from residences. Many of these technologies are inefficient (Figure 4) and some produce potentially harmful secondary products such as PM, ozone, formaldehyde and other VOCs. ${ }^{28,29}$ Filtration methods can re-emit filtered particles, harbouring microbial growth, and enhance the rates of chemical reactions that produce secondary pollutants.

1.2.3 Activities. Large, rapid changes to air quality can result from activities that generate indoor $\mathrm{PM}, \mathrm{NO}_{2}, \mathrm{CO}$ and VOCs. In school buildings, 

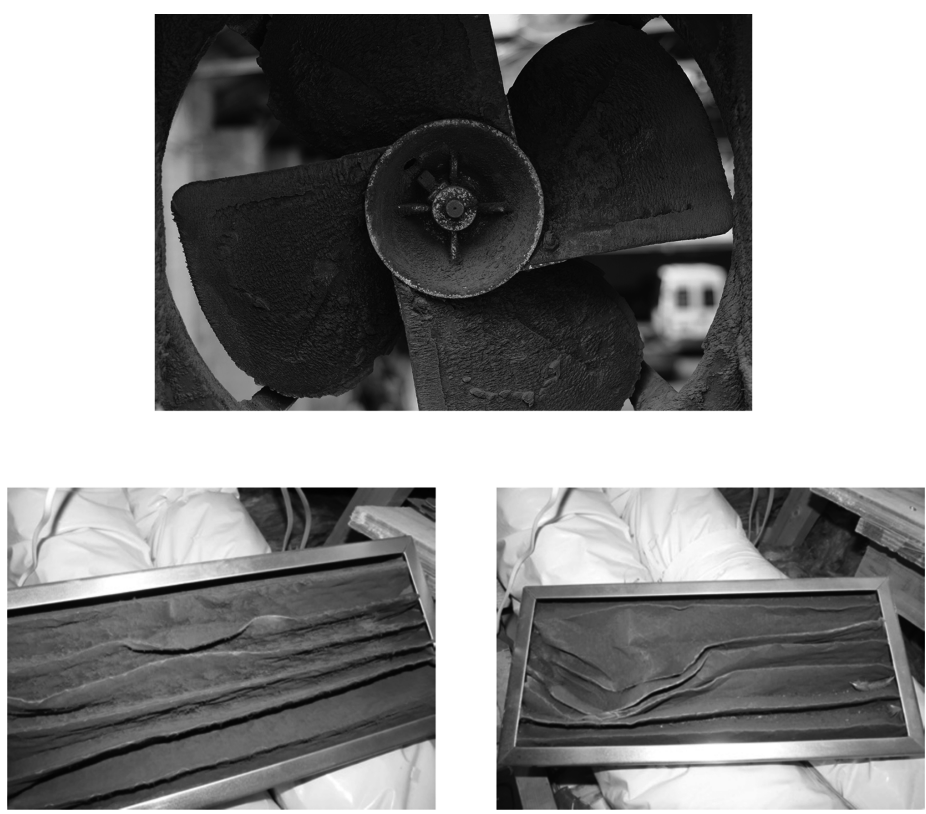

Figure 4 Left: old, dirty building ventilation fan. Reproduced with permission from Steven Lilley, RCPCH and RCP. Right: dirty ventilator filter. Reproduced with permission from Professor Tim Sharpe and RCPCH.

additional sources of pollutants include office equipment such as photocopiers, science laboratory activities, use of dry-erase markers and art supplies. Anything that disturbs the air and dust, such as cleaning or moving about the home, can re-suspend PM from cooking and burning into the air. ${ }^{30,31}$

\subsubsection{Cooking}

PM concentrations in the home vary throughout the day and increase in response to activities such as cooking. ${ }^{32,33}$ The decline in air quality is not limited to the kitchen. When cooking increased the concentrations of PM, a similar pattern was observed in both the kitchen and living room. During cooking, $\mathrm{PM}_{2.5}$ concentrations in kitchens are generally higher those found outside, especially in winter, and can remain elevated long after cooking ends. ${ }^{34}$ However, what remains unknown is whether particles generated by cooking are of equivalent toxicity to other sources of particulate pollution, e.g. traffic, diesel, secondary particles.

The design of the home and how we cook is also relevant. Ventilation is very important as indoor $\mathrm{PM}_{2.5}$ and $\mathrm{NO}_{2}$ concentrations are typically lower in kitchens with extractor fans. ${ }^{35}$ The most effective kitchen ventilation system is an extractor fan. Ideally, it should be mounted in a cooker hood that extracts directly to the outside and is located over the hob to cover all burners or rings. The fan should be switched on whenever cooking, even when using 
an oven, grill, or a toaster, used on its highest setting, and used for at least 10 minutes after cooking ends.

Modelling shows that open plan kitchens, which combine a kitchen with a living room, have lower PM concentrations, decreasing the exposure of cooks to PM but increasing the exposure of other family members. ${ }^{36}$ The browning of foods by frying, roasting, toasting, and grilling all increase PM emissions. The fragrances of cooking with spices are from the release of VOCs. ${ }^{37}$

Cooking with gas is more polluting than cooking with electricity because gas stoves, grills, and ovens are a major source of $\mathrm{NO}_{2}$ and carbon monoxide (CO). $\mathrm{NO}_{2}$ concentrations were higher in both the kitchen and living room in homes with gas cooking appliances. ${ }^{38}$ Homes with gas appliances had higher concentrations of $\mathrm{NO}_{2}$ than was found outdoors. ${ }^{39,40}$ During the winter, kitchens with gas appliances are found on average to have $\mathrm{NO}_{2}$ concentrations that are twice those found in kitchens with electric appliances, and to have elevated $\mathrm{NO}_{2}$ concentrations throughout the rest of the home. The air quality indoors can be worse than it is outside, and this is in part due to PM generated by cooking. A study in Oxford ${ }^{41}$ showed that indoor exposure to $\mathrm{PM}_{2.5}$ was higher than outdoor exposure. Measurements of $\mathrm{PM}_{10}$ in Birmingham, Wales, and Cornwall demonstrated higher concentrations indoors, although the composition of indoor $\mathrm{PM}_{10}$ was also influenced by outdoor sources. ${ }^{42,43}$

Without pollution generated indoors, indoor $\mathrm{NO}_{2}$ and $\mathrm{PM}$ concentrations are typically lower than outdoors. The CO in buildings is mostly due to infiltration of outdoor air, and without indoor sources, CO levels indoors are very similar to those outdoors. Modelling suggests that, without indoor sources of $\mathrm{NO}_{2}$ and $\mathrm{PM}_{2.5}, 40 \%$ and $50-70 \%$ respectively of these pollutants enters buildings from the outside air. ${ }^{44}$ When cooking or smoking occurs indoors, the average $\mathrm{NO}_{2}, \mathrm{CO}$, and $\mathrm{PM}$ concentrations can be much higher than outdoor levels. Suggestions to reduce cooking-related pollution are depicted in Figure 5.

\subsubsection{Burning}

Tobacco smoking is the most obvious and well known avoidable indoor air pollutant. The ban on smoking in public places has had the knock-on effect of making smoking indoors antisocial, especially in the presence of children (Box 1). However, there are other combustion sources of indoor pollution. Open fires and older wood-burning stoves emit a mixture of gases (including CO, nitrogen oxides, VOCs) and PM (including inorganic material, organic carbon, PAHs and acids). Burning of wet or unseasoned wood is especially polluting. The UK government recommends only burning approved solid fuels or wood with $<20 \%$ moisture content. ${ }^{45}$ A scheme identifies lesspolluting stoves, which are referred to as 'Defra Smoke Exempt Appliances'. Domestic burning can worsen outdoor air quality. It can also worsen air quality within the home. ${ }^{45,46}$ In the UK, living rooms with wood stoves had 


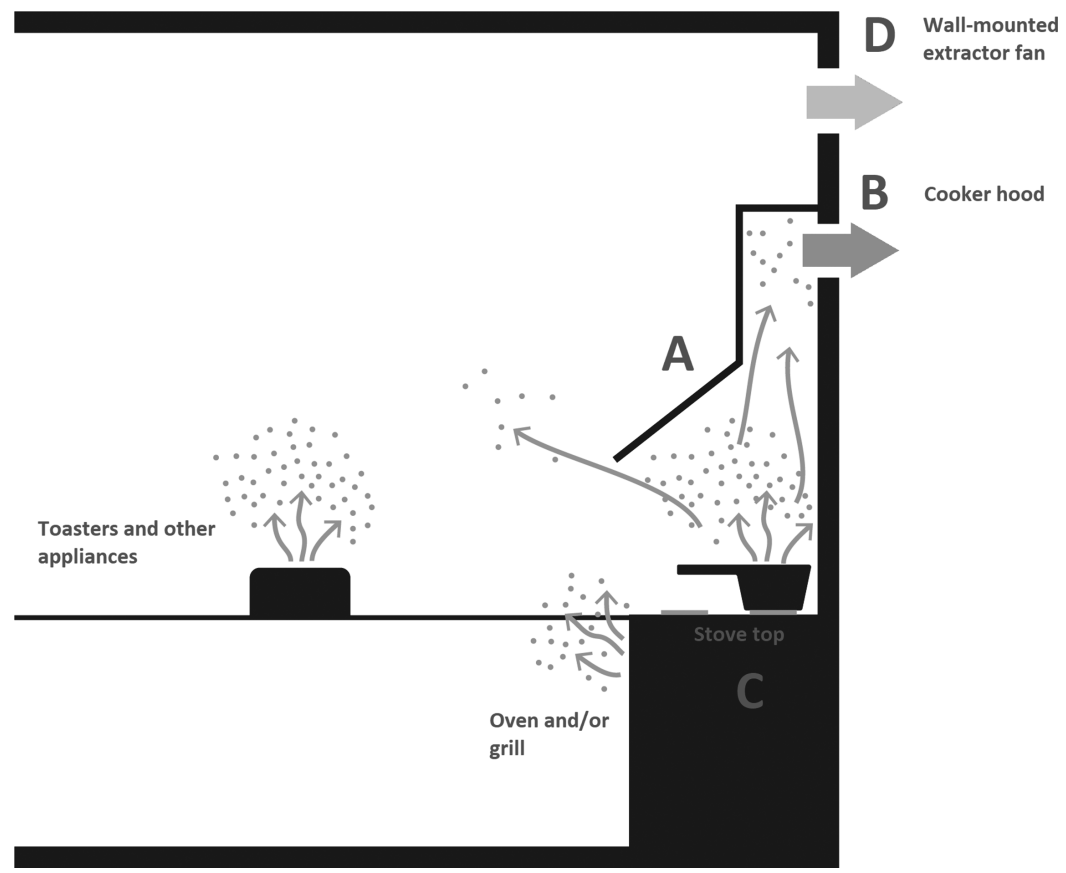

Figure 5 Recommendations when cooking. A: The cooker hood should cover all rings or burners. B: The cooker hood should extract the air outdoors. C: Cook on the back rings or burners whenever possible, especially during frying, to help the cooker hood capture as many pollutants as possible. Consider using other cooking appliances under the hood. D: If a cooker hood is not available: use a wall mounted extractor fan on its highest setting whenever cooking, and for 10 minutes afterwards. Otherwise, try to find another means to ventilate the room such as opening a window.

Reproduced with permission from RCPCH.

higher concentrations of pollutants than those with central heating, ${ }^{47}$ with this problem being worse in the colder winter months. For urban areas, the sources of burning are closer together and buildings can prevent pollutants from easily dispersing. However, in the UK, wood or solid fuel burning is more common outside cities; rural households had higher PAH levels than urban or sub-urban homes. ${ }^{48,49}$ On a smaller scale, candle and incense burning can also impair the air quality. In Danish homes, candles were the dominant source of indoor PM. ${ }^{50}$ Candles are less-polluting than incense, but both generally have lower emissions than cooking. ${ }^{51}$

\subsubsection{Consumer Products}

Consumer products for cleaning, polishing, indoor fragrances, or personal care and cosmetic products are a source of indoor air pollution. These products release a range of different VOCs that can be suspended in the air or settle in dust and on surfaces. Air concentrations of VOCs in the home are 
influenced by the products used, the furnishings and building materials, and the rate of ventilation. Indoor VOCs do not appear to be significantly influenced by outdoor sources. Homes near high volumes of traffic had similar levels of VOCs indoors as homes away from busy roads. The concentration of VOCs in the home is strongly correlated with the level of exposure for an individual. This shows that the home is the key factor in how residents are exposed to VOC pollution.

A European research project found that both acute and chronic exposure to some VOCs was related to irritative and respiratory health effects. ${ }^{52-54}$ This included acrolein, formaldehyde, benzene, naphthalene, d-limonene, and $\alpha$-pinene. These were emitted during household use of 15 consumer products, ${ }^{55,56} \mathrm{~d}$-limonene and $\alpha$-pinene also reacting with ozone indoors to produce PM and formaldehyde amongst other pollutants. Naphthalene can be present at very high concentrations in houses where deodorant or pest repellents are used. ${ }^{57,58}$ Exposure to high concentrations of naphthalene can irritate the eyes and respiratory system. Insect repellents and mothballs should be used with caution, especially in any rooms where young children spend time. Unexpectedly high concentrations of mono-terpines have also been found in UK homes. ${ }^{59}$

\subsubsection{Settled Dust and Vacuum Cleaning}

Settled dust is a source of pollutants, including PM, biological pollutants (from house dust mites and other pests, pet allergens, mould and fungi), SVOCs, pesticides, flame retardants, phthalates as endocrine disrupters and even peanut and other food allergenic proteins. ${ }^{60}$ Keeping a building clean is an obvious priority for many building owners and users. Vacuum cleaning is one of the simplest methods for clearing dust and is particularly important for those who suffer from asthma. However, vacuum cleaners can release and resuspend dust and allergens, presenting an additional source of exposure for susceptible populations. ${ }^{61}$ This happens both through the act of vacuuming disturbing the dust, and through emissions from the vacuum cleaner. It is important that the dust collection chamber retains the dust efficiently and is emptied regularly. Bacteria can survive for up to 2 months within these spaces, and then be released into the air when the vacuum cleaner is used again. ${ }^{61}$

\subsubsection{Pets and Plants}

Pets are a source of indoor allergens and for some sensitive members of the population, exposure to these allergens can exacerbate disease. Plants may also be a source of allergens in pollen, mould in the soil, or pesticides. The extent to which these pollutants will affect indoor air quality is highly variable. It depends on the plant species, the amount of pollutant released, and the differences in sensitivity to allergens between people. Apart from tests carried out in laboratory air-chambers, there is little evidence that specific plants can noticeably reduce indoor air pollutants in rooms of homes and schools. $^{62}$ 


\subsubsection{Moisture and Temperature Indoors}

Activities such as cooking, showering, or drying clothes indoors introduce moisture into the home. Cold floors, walls and surfaces can lead to condensation. As witnessed in recent times, water damage from leaks or flooding can have a major impact. The weather and season also affect indoor moisture, increasing when there are wet or high-humidity conditions outdoors. Moisture is a problem indoors because it promotes mould growth and other biological contaminants, such as house dust mites (Figure 6).

Humidifiers add moisture to the air to prevent dryness that can irritate some parts of the body, such as the skin and lips. Increasing the humidity can increase the release of formaldehyde from building materials and surfaces. ${ }^{63}$ Humidifiers can also increase the likelihood of damp, condensation on cold surfaces, and mould or fungal growth. ${ }^{64}$ Damp rooms can be controlled using a dehumidifier, but these can facilitate mould growth if stagnant water is left inside them. ${ }^{65}$ Humidity $>65 \%$ in an indoor environment encourages chemical reactions that leave a thin 'film' coating surfaces. ${ }^{66}$ This can increase the concentrations of potentially irritating chemicals indoors. ${ }^{67}$ Microbes are often associated with damp surfaces in homes and these can also emit reactive chemicals. ${ }^{68}$

Swimming pools are relatively uncommon in UK homes and schools but are still a source of moisture. Chlorine levels are relatively high in swimming pools and a range of by-products are formed when the chlorine interacts with organic matter. Some of these have carcinogenic properties. ${ }^{69}$ Evidence around childhood swimming and new-onset asthma is emerging. There need to be larger health studies to look at the risk to swimmers. Currently, that potential harm must be weighed up against the known benefits of exercise.
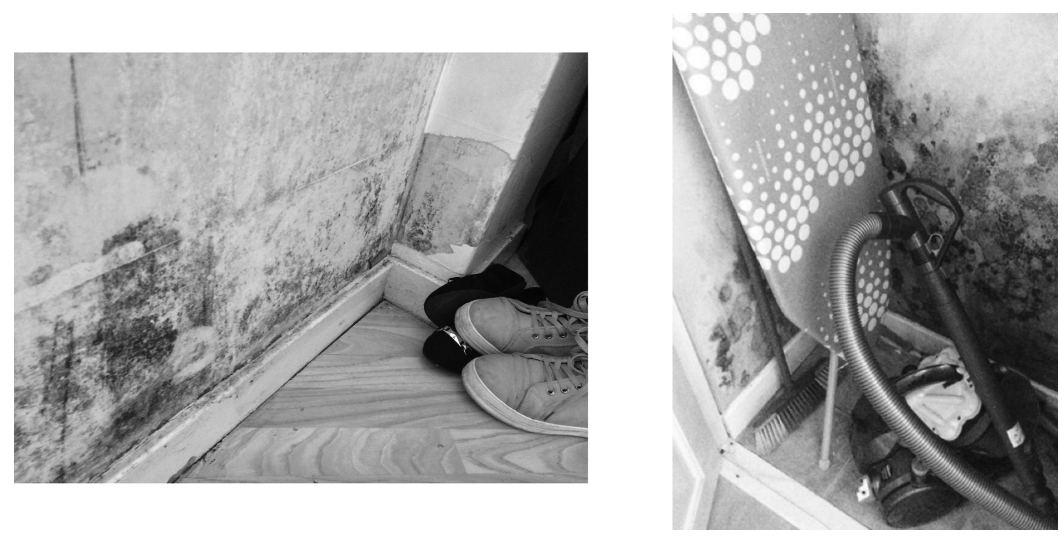

Figure 6 Left: mould growth and dampness. Right: dampness in a child's bedroom.

Reproduced with permission from Professor Tim Sharpe. 


\subsubsection{Heating and Ventilation}

High ventilation rates dilute indoor generated air pollutants but allow higher ingress of outdoor air pollutants. For example, by bringing outdoor air in, ventilation may also lead to higher indoor ozone concentrations. Ozone is very reactive and produces secondary pollutants from chemical reactions e.g. with nicotine or limonene. However, with enough ventilation the conditions for chemical reactions are disrupted and any secondary pollutants created would be quickly flushed out of the building. Other outdoor generated pollutants entering the building via ventilation can include $\mathrm{PM}$ and $\mathrm{NO}_{2}$. Higher temperature can also increase the emissions and chemical reactions between certain chemicals indoors. If they become warm, some plastics emit higher rates of VOCs, for example children's toys left near radiators or in direct sunlight.

Buildings with identical indoor pollution sources could still have very different indoor air. This will depend on the ventilation rates, heating patterns, behaviour of the people using the building, and outdoor climate. People will influence the ventilation and heating in homes and schools. This happens both intentionally, such as when altering thermostats or using windows and other means of ventilation, and unintentionally, such as when opening external doors to enter or leave the building.

\subsubsection{People as Sources of Pollution}

The presence of people indoors can significantly alter the air quality. This is because our skin oil contains compounds that can react with ozone to produce a range of VOCs. Humans breathe out carbon dioxide and VOCs. The exact contents of exhalation depend on the individual; age, gender, smoking habits, and diet each have an impact. ${ }^{70}$ Emissions from humans are called 'bio-effluents' and include the smells we associate with people. Smell can be an effective prompt to increase ventilation; it is a sign of insufficient ventilation. However, not all pollutants that cause poor indoor air quality are detectable by smell.

These emissions are more likely to have an impact in schools than homes. Classrooms hold a relatively high number of children for the space and may be inadequately ventilated. $\mathrm{CO}_{2}$ is currently used as an index of ventilation performance in the Government Guidance for Schools. ${ }^{71}$ Higher $\mathrm{CO}_{2}$ concentrations have been correlated to a decline in cognitive performance, such as the ability to concentrate, when levels are high. There is still uncertainty whether these effects are caused by $\mathrm{CO}_{2}$ itself, or related to other chemical or biological pollutants. ${ }^{72}$ A review of nearly two decades of research on the effects of classroom air quality on learning performance outcomes for children in elementary schools suggests that if ventilation rates were increased from 2 to $10 \mathrm{~L} \mathrm{~s}^{-1}$, there would be significant improvements in pupils' test performance and attendance $^{73}$ 


\section{Health Effects for Children}

A large majority of studies were concerned with exposures in the home, with a small number from the UK. Far fewer considered exposures in day care or at school, none of them set in the UK. Few studies directly considered the issue of poverty and associated socio-economic deprivation. Yet it is likely that, through excess indoor pollution, poor housing conditions are in part responsible for the stark social gradient of childhood disease.

Over $80 \%$ of studies linking adverse health to air pollution indoors are concerned primarily with respiratory health. There is a small literature on dermatitis and a range of other conditions. Almost all studies focussed on a specific pollutant or type of pollutant (such as mould or groups of chemicals). Damp and mouldy housing was the focus for a high proportion of studies. Studies looked at allergens in dust from house dust mites, pets, pests, and vermin. Others tested dust to estimate exposure to 'chemicals' including those of endocrine disrupting compounds (EDCs), pesticides, moulds, bacteria, and endotoxin(s). A few studies tested the indoor air for VOCs, $\mathrm{NO}_{2}, \mathrm{CO}_{2}$, or PM.

\subsection{Birth and Infancy}

2.1.1 Moisture and Mould. Evidence regarding the association between exposure to moisture and mould and respiratory problems in infancy strongly suggests an adverse interaction. In a European birth cohort, ${ }^{74}$ the severity of moisture damage in the kitchen and visible mould in the main living area were associated with an increased risk for wheezing in the first 18 months. These results were not replicated in a birth cohort in the USA. ${ }^{75,76}$ In US children, some species of fungi, found in domestic dust samples, were correlated with rhinitis and wheezing during infancy. Similarly, in a birth cohort of Italian children, ${ }^{77}$ visible mould in the home significantly increased the risk of hospitalization for a respiratory infection (bronchiolitis) during infancy (Figure 6). In Finland, a study of 398 children (aged up to 18 months) found those diagnosed with wheezing were more likely to have damp homes. This was assessed by the severity of moisture damage in the kitchen and visible mould in the living area. ${ }^{78}$ Amongst 103 infants at risk of asthma in the USA, high levels of Penicillium mould were a significant risk factor for wheeze in the first year. The analysis was adjusted to remove the influence of factors like the season in which damp was assessed, endotoxin levels (a marker for bacteria levels), and whether the child attended day care or a nursery.

\subsubsection{Chemicals}

\subsubsection{Household Products}

Ventilation could mitigate the effects of indoor air pollution during pregnancy. A study looked at the outcomes of births in women who were regular or frequent users of household cleaning products. Those who kept the windows open for at least half the day had no increased risk of having a 
pre-erm or low birthweight child. ${ }^{79}$ There was an increased risk of preterm birth for regular users of nail polish or hairspray for at-home mothers, but not for mothers working out of the home.

Redecorating or refurnishing the home can release VOCs and cause a higher than usual exposure. In the Lifestyle and environmental factors and their Influence on Newborns Allergy risk (LINA) birth study, home decorating increased the risk of infants $<1$ year old being diagnosed with wheeze. The health effects were attributed to styrene, ethylbenzene, octane, 1butanol, tridecane and $o$-xylene. ${ }^{80}$ It appears that exposure during infancy was less detrimental than during pregnancy and changing the flooring material was highlighted as a concern. The Leipzig Allergy Risk Children Study (LARS) found redecoration of an apartment increased the risk of infants having acute inflammation of their airways. ${ }^{81}$ When 25 VOCs were measured in the bedrooms of 475 infants with allergic risk factors, those exposed to higher concentrations of styrene and benzene had more respiratory infections (odds ratio (OR) 5.6, 95\% confidence interval 1.3-24.0).

Similarly, in the Pollution and Asthma Risk Infant Study (PARIS), indoor renovation was reported to be a risk factor for respiratory symptoms or allergies. ${ }^{82}$ Evidence from that cohort suggests that the risk may be attributable to formaldehyde. ${ }^{83,84}$ In the Avon Longitudinal Study of Parents and Children (ALSPAC), a maternal composite household chemical exposure score was associated with an increased risk of wheeze in the first 18 months after birth. ${ }^{85}$ Amongst 257 children in Krakow with pre- and post-natal exposure to PAHs, there was an increased risk of wheezing. ${ }^{86}$

\subsubsection{Endocrine Disrupting Chemicals (EDCs)}

This heterogenous group includes synthetic chemicals used as industrial solvents and lubricants and their by-products (such as polychlorinated biphenyls, dioxins), plastics (bisphenol A), plasticizers (phthalates), and some pesticides (such as methoxychlor or chlorpyrifos). They tend to accumulate in household dust. They are often designed to be 'long-lasting' and so they can remain in the home for very long periods. Exposure to EDCs has been linked to a variety of adverse reproductive, malignant, and metabolic outcomes including childhood obesity and infertility. There is also growing concern over the long-term effects of exposures in very early life. ${ }^{87}$

\subsubsection{Congenital Abnormalities}

The evidence that exposure to air pollutant chemicals may increase congenital abnormalities is relatively weak. In a Chinese study, women's exposure to indoor air pollution during pregnancy increased the risk of neural tube defects in their babies. ${ }^{88}$ However, the study was of mothers with a specific genetic variant and it may not apply to other women. A small study in France found a strong association between pregnant women's exposure to EDCs at work, and a birth defect where the urethra's opening develops on the underside of the penis (hypospadias). ${ }^{89}$ 
2.1.3 Particulate Air Pollution. A systematic review of 84 studies reported that many types of particulates were associated with low birth weight and decreases in birth weight. The review also highlighted that there were some inconsistencies in the included studies. A Taiwan Birth Cohort Study, involving 15773 births, found incense burning was associated with lower birth weight in boys (18g) but not girls. ${ }^{90}$ Smaller head circumferences were found in both genders.

\subsubsection{Cooking Fumes}

In Rome, seed oil for cooking was associated with an increased risk for a type of respiratory infection (bronchiolitis) in infancy. ${ }^{91}$

\subsection{Pre-School Children}

2.2.1 Moisture and Mould. The evidence for an association of dampness or mould on adverse respiratory outcomes in pre-school children is conflicting. In a Polish birth cohort, a damp or mouldy home was associated with persistent wheeziness up to the age of 2 years. ${ }^{92}$ In a large casecontrol study from New Zealand, the adjusted risk of pneumonia in preschool children was doubled among children who slept in a bedroom where mould was visible. ${ }^{93}$ Similarly, in the only study from the UK, a damp home was independently associated with a higher risk of asthma and associated allergies. ${ }^{94}$

In contrast, several studies have failed to find a link between mould and childhood respiratory diseases. A study in Sweden found no link between children's asthma and the levels of mould in dust collected from their bedrooms. ${ }^{95}$ In the USA, there was no association between mould in the home and recurrent night cough in children aged $\leq 3$ years old. ${ }^{96}$ In an Italian study of children $<5$ years old, there was no significant difference in damp or mould in the child's bedroom when comparing those who had had bronchiolitis with a group who had not. ${ }^{90}$ In a study of 408 children (aged 2-3 months) with a family history of allergic disease or asthma, bedroom dust samples were collected and tested for fungi (Figure 6). Children whose bedroom floor had high levels of yeasts were at a reduced risk of wheeze at any age, and a reduced risk of asthma by age $13 .{ }^{97}$ In studies of day-care facilities, measures of moisture and mould did not have a clear effect on respiratory health among children attending day care in Portugal ${ }^{98}$ or in Oslo. ${ }^{99}$

2.2.2 Chemicals. In preschool children, exposure to certain air pollutant chemicals increases respiratory problems and may increase dermatitis. The findings of a systematic review of ten studies ${ }^{100}$ suggest that high exposures to $\mathrm{NO}_{2}$ and VOCs in the home increase the risk of developing wheezing respiratory diseases before the age of 5 years. Amongst 150 children between 2 and 6 years of age with a physician diagnosis of asthma in Baltimore, higher $\mathrm{NO}_{2}$ concentrations were associated with increased 
cough and nocturnal symptoms. After adjustments for confounders were made there was no increase in use of healthcare. The presence of a gas stove or the use of a space heater were independently associated with higher $\mathrm{NO}_{2}$ concentrations. ${ }^{101}$ In Polish children, the frequency of wheezing was significantly associated with postnatal indoor exposures to PAHs. ${ }^{92}$ In South Korean children, there was a significant association between VOC exposures in the bedroom and atopic dermatitis at the age of 3 years. ${ }^{102}$ In one disastrous use of chemicals in the home, disinfectants used for domestic humidifiers in South Korea caused serious lung injuries. There were deaths including both young children and their parents. The problem promptly disappeared when the sale of these disinfectants was prohibited in 2011. ${ }^{103}$

In a case-control study of 500 Danish children aged 3-5 years, the dust from both home and day-care environments was tested to measure phthalates. One phthalate (diethyl phthalate) was found in higher proportions for children with asthma and allergies, compared to children without preexisting health conditions. ${ }^{104}$ A different phthalate (diethylhexlyphthalate) was associated with current wheeze. There was no significant difference found for two other phthalate derivatives (DiBP and BBzP).

In a study in Sweden, of 198 children with asthma and allergy compared to 202 healthy controls, bedroom air samples were tested for eight types of VOCs. Propylene glycol and glycol ethers were associated with a greater likelihood of asthma, rhinitis, and eczema. The analysis was adjusted to control the effects of the child's gender, exposure to secondary smoking, parents' allergies, construction period of the building, and for the presence of limonene (a terpene used in cleaning fluids and air fresheners), cat and dog allergens, or selected phthalates. ${ }^{105}$

A small case-control study from the USA suggested that developmental delay before the age of 5 years may be associated with levels of phthalates in the dust at home. ${ }^{106}$ Although the levels were not significantly associated with autism spectrum disorder, higher indoor dust concentrations of diethyl phthalate were associated with greater hyperactivity, impulsivity, and inattention.

2.2.3 Carbon Dioxide Exposure. From Denmark, despite only one day care centre having $\mathrm{CO}_{2}$ levels $>1000$ ppm, children missed fewer days due to illness when the $\mathrm{CO}_{2}$ levels were reduced. ${ }^{107}$ In Portugal, $\mathrm{CO}_{2}$ levels in day-care centres were associated with wheeze. The $\mathrm{CO}_{2}$ concentrations were reduced by opening windows or internal doors, and by higher wind speeds. ${ }^{108}$ These studies use $\mathrm{CO}_{2}$ levels as a proxy for the ventilation and poor indoor air quality. The $\mathrm{CO}_{2}$ concentration is reduced by increasing the intake of air; this change in the air may be responsible for the health outcomes rather than reduction in $\mathrm{CO}_{2}$ alone.

2.2.4 Allergens and Endotoxin. The evidence on the impact of allergens and endotoxin is variable. Two studies of young children in the USA ${ }^{109,110}$ 
did not find a relationship between the levels of pet allergen in the home and rates of wheeze or eczema. Furthermore, a longitudinal study of children in The Netherlands followed to the age of 5 years failed to find any relationship between cat and house dust mite allergen exposures and development of respiratory symptoms. ${ }^{111}$ In a community study with a low prevalence of pet keeping and low mite allergen levels, exposure to cat allergens in early life increased the risk of late childhood asthma and bronchial hyper-responsiveness (BHR). There was no effect on the risk found for dog allergens, endotoxin and $\mathrm{B}^{1,3}$-glucans. ${ }^{112} \mathrm{~A}$ meta-analysis of observational studies demonstrated that endotoxin was positively associated with wheeze in infants and toddlers, but not with asthma in school-aged children. $^{113}$

2.2.5 Particulate Matter. Exposure to particulate matter (PM) has been shown to increase the risk of asthma, dermatitis, and eczema. In a survey of children in the USA, ${ }^{114}$ eczema, but not wheeze, was associated with high exposures (mean $85 \mu \mathrm{g} \mathrm{m}^{-3}$ ) to PM. In one study, PM measured using an innovative mobile sampler (the Pre-Toddler Inhalable Particulate Environment Robotic (PIPER) was used. In 75 households with children $<5$ years old, the risk of asthma was increased in those with the highest levels of larger $\mathrm{PM}_{18}$. This was discovered when using the mobile PIPER device, but not by the stationary samplers. ${ }^{115}$ Amongst children aged 2-6 years in Baltimore, increases in home PM levels were associated with increased respiratory symptoms and use of asthma-rescue medication. Increases in $\mathrm{PM}_{2.5}$ were also associated with symptoms during exercise. ${ }^{116}$

There is also some evidence of PM having an adverse effect on children's skin. In a study of 425 children in a Korean kindergarten, atopic dermatitis and eczema were reduced when an enhanced cleaning programme was used by the kindergartens to reduce PM levels. ${ }^{117}$

\subsection{School-Age Children}

2.3.1 Moisture and Mould. Many studies have explored the effects of indoor damp or mould in school-aged children, although just one was of children in the UK. ${ }^{118}$ The majority were concerned with damp in the home, in most cases described by parents. Two studies were of damp in schools. The studies of domestic damp suggest modest associations with asthma-like symptoms, rhinitis, and eczema. Several were reviewed by Castro-Rodriguez et al. ${ }^{119}$ who reported a summary OR of $\sim 1.5$ for the presence of mould or dampness at home and asthma or wheeze. Studies of consecutive cohorts of children in Sweden suggest that the risks probably diminish as children get older. ${ }^{120,121}$ In the UK study, a damp home in infancy was independently related to atopic asthma over the subsequent 7 years. Findings from studies in Italy, ${ }^{122}$ Australia, ${ }^{123}$ and Sweden $^{120}$ suggest that between 7 and $14 \%$ of childhood asthma can be attributed to damp housing. 
Two studies compared the school environment and the health of pupils in Spain, The Netherlands and Finland. ${ }^{124}$ In the Finnish group - but not the others - there was an association between a damp school and wheeze, rhinitis, and school absence from respiratory illnesses. In a survey of 1000 children in Denmark, ${ }^{125}$ there were no significant associations between symptoms and mould levels in naturally ventilated classrooms. Importantly, this was not the case for classrooms with exhaust or mechanical ventilation systems. In these classrooms, higher mould levels were related to the children experiencing increased eye and throat irritation, nasal congestion, and itchy skin.

Similar findings have been reported in schoolchildren from 21 schools in five European countries. ${ }^{126}$ In a Polish secondary school, breathlessness and cough after physical exercise were related to the humidity level in the gymnasium. ${ }^{127}$ In a high-risk birth cohort in the USA, in which one parent was atopic, exposure to moulds was assessed by the Environmental Relative Mouldiness Index (ERMI). ${ }^{128}$ Mould exposure at 1 , but not at 7 years, was associated with a significant increase in the risk for asthma at 7 years of age. In a Colombian survey of children (from birth to 17 years), mould exposure was noted to be a risk factor for asthma-related absences from school. ${ }^{129}$

While the evidence about damp or mould is mostly about respiratory and skin conditions, a study of German children ${ }^{130}$ suggested that those in damp homes have more trouble sleeping through the night. In addition, in Upstate New York, school absenteeism was significantly associated with school building condition, i.e. is visible mold, humidity, and poor ventilation. ${ }^{131}$

2.3.2 Chemicals. Several studies have shown an association between various chemicals and adverse respiratory and skin problems. Five studies examined the effects of VOCs in the homes of school-age children and highlighted an association with respiratory problems. In France ${ }^{132}$ levels of benzene in the home were related to non-atopic asthma. In Portuguese homes, similar findings were found for toluene and acetaldehyde. ${ }^{133}$ In homes in the USA, four different VOCs were associated with higher risk for wheeze between colds and also asthma diagnosis. ${ }^{134}$ Amongst Alaskan native children, VOCs, primary wood heat, and a $\mathrm{PM}_{2.5}$ level $>25 \mathrm{ug} \mathrm{m}^{-3}$ were associated with a higher risk for cough between colds and an asthma diagnosis. ${ }^{134}$ In Canadian homes, where 47 VOCs were measurable, significant associations with deficits in lung function were observed for all, apart from naphthalene. ${ }^{135}$

In a comparison of French urban and rural homes, urban homes had more indoor pollutants. In both urban and rural homes, acetaldehyde and toluene were significantly associated with a higher risk of asthma. ${ }^{136}$ In a survey of over 6500 French schoolchildren, rhino-conjunctivitis and asthma were significantly associated with high levels of formaldehyde or acrolein in classrooms. ${ }^{137}$ In Japan, where it is common for children to sit on the floor, levels of phthalates in dust were associated with higher prevalence of rhinitis, conjunctivitis, and dermatitis. ${ }^{138}$ 
Three high-quality studies of oxides of nitrogen in the home have been conducted. In the strongest of these, a longitudinal study of 1300 children with asthma in the USA, levels of $\mathrm{NO}_{2}>14.3 \mathrm{ppb}$ were associated with increased asthma severity. ${ }^{139}$ In a French school study ${ }^{137}$ the prevalence of asthma was higher in classrooms with higher levels of $\mathrm{NO}_{2}$.

A study of 9-year-olds in Spain ${ }^{140}$ used MRI scanning to study the impact of indoor pollution on the brain. This found a potential link between higher levels of PAHs (specifically, benzo(a)pyrene) at school and a reduced size of caudate nucleus. This area of the brain plays a role in controlling motor functions, as well as learning and memory.

Seven studies, all but two set in the USA, were concerned with pesticides. In a study of $>14000$ American children, pesticide use in the kitchen or dining room significantly increased the odds of childhood wheeze and dry cough. ${ }^{141}$ In Austria, phthalates and compounds used in pesticides, and found in the indoor PM, were associated with reduced cognitive performance in 6-8-year-olds. Increased $\mathrm{CO}_{2}$ levels were also associated with reduced performance. ${ }^{142}$ There are case-control studies which suggest a risk of childhood cancers or multiple sclerosis from pesticide use at home, but the collective evidence is weak.

2.3.3 Allergens and Endotoxin. Several birth cohort studies have attempted to relate the onset of school-age asthma to measurements of domestic allergens made early in life. With respect to allergens from pets and from house dust mite, the evidence is very largely negative. Cross-sectional evidence, however, suggests a role for cockroach and mouse allergens in US homes. For example, in children with asthma, the concentration of cockroach (but not dust mite) allergen in household dust was significantly related to the risk of hospitalization. This was true even after adjustments were made to account for different asthma severity and socio-economic status. ${ }^{143}$

Among children living in US inner cities where socio-economic deprivation is high, mouse allergen levels in bedroom dust were associated with greater asthma morbidity. ${ }^{144}$ Similarly, a US study focused on children whose parents had a history of asthma or allergy. In this group, current mouse exposure in each of the first 7 years of life increased the risk of wheeze. ${ }^{145}$ In contrast, in another US study, among 442 inner-city children, higher levels of pet or pest allergens in infancy were associated with a lower risk of asthma. ${ }^{146}$ Furthermore, Mendy and colleagues ${ }^{113}$ systematically reviewed the evidence on endotoxin and based on 19 studies, reported that higher levels were associated with a lower risk of asthma and related symptoms.

2.3.4 Particulate Matter. A small number of studies concerned particulate matter measured in the home and the health of school-age children. In three small studies of American children, levels of $\mathrm{PM}_{2.5}$ were associated with a variety of respiratory symptoms. ${ }^{116,134,147}$ In one, the 
increased risk of respiratory disease was only found for overweight children. Exposure to fine particulate matter $\left(\mathrm{PM}_{2.5}\right)$ during pregnancy was associated with increased susceptibility to respiratory infections by 7 years old. ${ }^{148}$ In the USA, for 44 asthmatic children aged between 1 and 16 years, indoor but not outdoor $\mathrm{PM}_{2.5}$ was associated with reductions in lung function. ${ }^{149}$

2.3.5 Carbon Dioxide Exposure. A European-Union-funded study demonstrated that $66 \%$ of school children in Norway, Sweden, Denmark, France, and Italy were exposed to $\mathrm{CO}_{2}$ concentrations $>1000 \mathrm{ppm}$. Children exposed to the higher levels were at risk for dry cough (OR 2.99, 95\% CI 1.65-5.44) and rhinitis (OR 2.07, 95\% CI 1.14-3.73). ${ }^{150}$ Similarly, in China the mean $\mathrm{CO}_{2}$ concentration was $>1000 \mathrm{ppm}$ in $45 \%$ of classrooms and was associated with an increased risk of asthma and requirement for asthma medication. ${ }^{151}$ Furthermore, in Washington and Idaho, $45 \%$ of classrooms had a $\mathrm{CO}_{2}$ concentration $>1000 \mathrm{ppm}$. These classrooms with high $\mathrm{CO}_{2}$ concentrations had reduced attendance at school. Over a year these high levels of $\mathrm{CO}_{2}$ were associated with a $0.5 \%$ decrease in average daily attendance, which for each classroom was an increase in absences of between 10 and $20 \%{ }^{152}$ In Aberdeen, higher average $\mathrm{CO}_{2}$ concentrations were also linked to lower attendance. Using a time-weighted average, for each $100 \mathrm{ppm}$ increase in $\mathrm{CO}_{2}$ concentrations, there was a reduction in annual school attendance of $0.2 \%$. This is roughly equivalent to half a day of school missed per annum. ${ }^{153}$ In Californian elementary schools, increasing the ventilation rates for classrooms reduced the level of absences. ${ }^{154}$

Elevated $\mathrm{CO}_{2}$ concentrations have been shown to also reduce the power of attention by $5 \% .^{155,156}$ Increasing ventilation rates in schools with mechanical systems has installation and running costs. Whether by natural or mechanical means, increased ventilation could raise the overall heating or air-conditioning bills. However, the likely net annual costs were calculated as $<0.1 \%$ of typical public spending on elementary and secondary education in the USA. ${ }^{157}$ In all these studies $\mathrm{CO}_{2}$ concentrations have been used as a proxy for overall ventilation.

\section{The Importance of Indoor Air for the COVID-19 Pandemic}

At the time of preparing this summary of indoor air and the health of children, the UK is in the grip of the Covid-19 pandemic. The 'lock-down' this has entailed means that traffic-related pollution has fallen dramatically, especially $\mathrm{NO}_{2}$. For example, $\mathrm{NO}_{2}$ concentrations at busy roadside sites such as the Marylebone Road and Euston Road in London, decreased by 55 and $36 \%$ respectively, with an average reduction across the City of $21.5 \%{ }^{158} \mathrm{~A}$ separate study found that in Manchester's city centre there has been a $70 \%$ reduction in NOx since the lockdown began. In contrast $\mathrm{PM}_{2.5}$ has either 
stayed the same or has increased due to particles (largely secondary particles) being blown in from Northern Europe by strong easterly winds. Similarly, higher than normal levels of ozone occurred because of the fall in $\mathrm{NO} x$ and sunny conditions. Due to significantly elevated outdoor $\mathrm{O}_{3}$ concentrations during summer, summer indoor concentrations are typically elevated due to ventilation. ${ }^{159}$ This is important as indoor ozone initiates indoor chemistry. ${ }^{160}$ Linked to this, one might expect more cleaning to happen indoors as people clean themselves and internal surfaces more frequently. For instance, using an established indoor air chemistry model, ${ }^{161}$ it was found that the lockdown conditions could produce indoor ozone concentrations that were up to $50 \%$ higher than before lockdown. In addition, during a typical cleaning event, whilst indoor PM concentrations were enhanced by $\sim 3 \mu \mathrm{g} \mathrm{m}^{-3}$ before the lockdown, during the lockdown, this was $>6 \mu \mathrm{g} \mathrm{m}^{-3}$ owing to additional production of secondary organic aerosol initiated by the additional $\mathrm{O}_{3}$. Over the same 6-8-week period, changes to indoor activity meant that children were exposed to a higher a concentration of $\mathrm{PM}_{2.5}$ from additional time spent cooking at home and using gas hobs and ovens for roasting meat and vegetables. These remarkable changes to the air we breathe will most likely have effects on human health, but at this time the outcomes are unclear.

The indoor environment is also the location where most respiratory viral transmission between people occurs and Covid-19 is no exception. Indeed, it is important, that national authorities acknowledge the stark reality that this virus, along with other respiratory viruses, spreads through air, and therefore that adequate control measures be put in place to prevent further spread of the SARS-CoV-2 virus; specifically via suitably designed and maintained ventilation. ${ }^{162,163}$ There remains lack of sufficient evidence to specify and quantify the minimum ventilation requirements in buildings, in relation to the spread of infectious diseases via the airborne route as well as taking account of the direction of airflow, and its control, since these can be as critical as ventilation in itself. ${ }^{164}$ Added to this is the possibility that air pollution itself increases SARS-CoV-2 transmission and mortality. ${ }^{165-167}$ Taking these dramatic events into account, there can never be a more important time to take account of the built environment to minimize viral transmission through environmentally mediated pathways. $^{168,169}$

The COVID-19 epidemic has also emphasised the broader and long-lasting impacts on children's health of poor quality in the built environment, through several pathways including indoor air quality. A specific example is overcrowding in housing: it can affect some of the non-infectious pollutants mentioned earlier (e.g. $\mathrm{CO}_{2}$, moisture/dampness), as well as transmission of infectious diseases, making self-isolation and home-schooling difficult if not impossible. It is worth noting that Black, Asian and Ethnic Minority households in England are more likely to be overcrowded in all tenures and socio-economic groups, ${ }^{170}$ and that the current statutory approach to 
defining overcrowding in English housing focuses primarily on privacy (rather than air quality), with children $<10$ years of age not counted for overcrowding purposes.

Though Covid-19, on the whole, is a less severe disease in children, ${ }^{171}$ it can present as a severe systemic illness with some similarity to Kawasaki Disease. ${ }^{172}$ Children are also considered to be key vectors of transmission when asymptomatic or with mild disease. ${ }^{173}$ Since, as repeatedly stated in this commentary, children spend a very large part of time indoors, and to an even greater extent during lock down, their role in harbouring and transmitting the virus in the indoor setting becomes critical. Finally, the emerging evidence that air pollution is a risk factor for acquiring Covid-19 disease and its mortality it seems highly plausible that children are rendered more vulnerable to Covid-19 due to health conditions exacerbated by poor indoor air quality.

\section{References}

1. A. L. Chiew and N. A. Buckley, Carbon monoxide poisoning in the 21 st century, Crit. Care, 2014, 18, 221.

2. R. Sheu, C. Stönner, J. C. Ditto, T. Klüpfel, J. Williams and D. R. Gentner, Human transport of thirdhand tobacco smoke: A prominent source of hazardous air pollutants into indoor non-smoking environments, Sci. Adv., 2020, 6, eaay4109.

3. J.-K. Kang, S. Seo and Y. W. Jin, Health Effects of Radon Exposure, Yonsei Med. J., 2019, 60, 597-603.

4. R.-T. Lin, M. J. Soeberg, L.-C. Chien, S. Fisher, J. Takala, R. Lemen, T. Driscoll and K. Takahashi, Bibliometric analysis of gaps in research on asbestos-related diseases: declining emphasis on public health over 26 years, BMJ Open, 2018, 8, e022806.

5. S. Oeder, R. A. Jörres, I. Weichenmeier, G. Pusch, W. Schober, F. Pfab, H. Behrendt, R. Schierl, A. Kronseder, D. Nowak, S. Dietrich, E. Fernández-Caldas, J. Lintelmann, R. Zimmermann, R. Lang, J. Mages, H. Fromme and J. T. Buters, Airborne indoor particles from schools are more toxic than outdoor particles, Am. J. Respir. Cell Mol. Biol., 2012, 47, 575-582.

6. R. M. Harrison, J. M. Delgado-Saborit, S. J. Baker, N. Aquilina, C. Meddings, S. H. Matthews, S. Vardoulakis and H. R. Anderson. 2009. Measurement and Modeling of Exposure to Selected Air Toxics for Health Effects Studies and Verification by Biomarkers. Boston: Health Research Institute (Research Report 143).

7. Committee on the Medical Effects of Air Pollutants. 2004. Guidance on the effects on health of indoor air pollutants. https:/webarchive. nationalarchives.gov.uk/20120104230915/http:/www.dh.gov.uk/prod_ consum_dh/groups/dh_digitalassets/@dh/@ab/documents/ digitalasset/dh_096801.pdf. 
8. E. Aristodemou, L. M. Boganegra, L. Mottet, D. Pavlidis, A. Constantinou, C. Pain, A. Robins and H. ApSimon, How tall buildings affect turbulent air flows and dispersion of pollution within a neighbourhood, Environ. Pollut., 2018, 233, 782-796.

9. D. J. Hall and A. M. Spanton Ingress of External Contaminants into Buildings - A Review. 2012 Envirobods Ltd. https://admlc.files. wordpress.com/2014/05/admlc-r7-2012-1.pdf.

10. W. Leal Filho, L. Echevarria Icaza, V. O. Emanche and A. Quasem Al-Amin, An Evidence-Based Review of Impacts, Strategies and Tools to Mitigate Urban Heat Islands, Int. J. Environ. Res. Public Health, 2017, 14, pii: E1600.

11. U. T. Tomizawa, A. Tokoro, M. Aoki, M. Hishiki, T. Yamada and N. Kunugita, . Gaseous chemical compounds in indoor and outdoor air of 602 houses throughout Japan in winter and summer, Environ. Res., 2015, 137, 364-372.

12. K. Apte and S. Salvi Household air pollution and its effects on health, Faculty Res. 2016; 5. pii: F1000 Faculty Rev-2593. eCollection 2016, https://doi.org/10.12688/f1000research.7552.1.

13. C. Kornartit, R. S. Sokhi, M. A. Burton and K. Ravindra, Activity pattern and personal exposure to nitrogen dioxide in indoor and outdoor microenvironments, Environ. Int., 2010, 36, 36-45.

14. S. Vardoulakis, S. Dimitroulopoulou, J. E. Thornes, K.-M. Lai, J. Taylor, I. Myers, C. Heaviside, A. Mavrogianni, C. Shrubsole, Z. Chalabi, M. Davies and P. Wilkinson, et al., Impact of climate change on the domestic indoor environment and associated health risks in the UK, Environ. Int., 2015, 85, 299-313.

15. Park and Ikeda, Variations of formaldehyde and VOC levels during 3 years in new and older homes, Indoor Air, 2006, 16, 129-135.

16. T. Salthammer, Data on formaldehyde sources, formaldehyde concentrations and air exchange rates in European housings, Data Brief, 2019, 22, 400-435.

17. Y. Y. Maruo, T. Yamada, J. Nakamura, K. Izumi and M. Uchiyama, Formaldehyde measurements in residential indoor air using a developed sensor element in the Kanto area of Japan, Indoor Air, 2010, 20, 486-493.

18. P. Lovreglio, A. Carrus, S. Iavicoli, I. Drago, B. Persechino and L. Soleo, Indoor formaldehyde and acetaldehyde levels in the province of Bari, South Italy, and estimated health risk, J. Environ. Monit., 2009, 11, 955-961.

19. F. Villanueva, A. Tapia, M. Amo-Salas, A. Notario, B. Cabañas and E. Martínez, Levels and sources of volatile organic compounds including carbonyls in indoor air of homes of Puertollano, the most industrialized city in central Iberian Peninsula. Estimation of health risk, Int. J. Hyg. Environ. Health, 2015, 218, 522-534.

20. M. Noguchi and A. Yamasaki, Volatile and semivolatile organic compound emissions from polymers used in commercial products during thermal degradation, Heliyon, 2020, 6, e03314. 
21. GROW.DDG1.C.4. Agreed EU-LCI values - substances with their established EU-LCI values and summary fact sheets 15/12/2019; Last update: 21/02/2020. https://ec.europa.eu/docsroom/documents/39985.

22. M. Kruza, A. C. Lewis, G. C. Morrison and N. Carslaw, Impact of surface ozone interactions on indoor air chemistry: a modelling study, Indoor Air, 2017, 27, 1001-1011.

23. J. Taylor, C. Shrubsole, P. Symonds, I. Mackenzie and M. Davies, Application of an indoor air pollution metamodel to a spatially distributed housing stock, Sci. Total Environ., 2019, 667, 390-399.

24. E. Malliari and O. I. Kalantzi, Children's exposure to brominated flame retardants in indoor environments - A review, Environ. Int., 2017, 108, 146-169.

25. Furniture \& Furnishings (Fire) (Safety) Regulations update 'imminent'. The British Furniture Confederation. June 24th 2019. https:// britishfurnitureconfederation.org.uk/furniture-furnishings-fire-safetyregulations-update-imminent-says-minister/.

26. M. MacNeill, J. Kearney, L. Wallace, M. Gibson, M. E. Héroux, J. Kuchta, J. R. Guernsey and A. J. Wheeler, Quantifying the contribution of ambient and indoor-generated fine particles to indoor air in residential environments, Indoor Air, 2014, 24, 362-375.

27. Medical Advisory Secretariat, Air cleaning technologies: an evidencebased analysis, Ont Health Technol. Assess Ser., 2005, 5, 1-52.

28. Y. P. Zhang, J. H. Mo, Y. G. Li and J. Sundell, Can commonly used fandriven air cleaning technologies improve indoor air quality? A literature review, Atmos. Environ., 2011, 45, 4329-4343.

29. J. A. Siegel, Primary and secondary consequences of indoor air cleaners, Indoor Air, 2016, 26, 88-96.

30. L. A. Wallace, H. Mitchell, G. T. O’Connor, L. Neas, M. Lippmann, M. Kattan, J. Koenig, J. W. Stout, B. J. Vaughn, D. Wallace, M. Walter, K. Adams and L. J. Liu, Inner-City Asthma Study. Particle concentrations in inner-city homes of children with asthma: the effect of smoking, cooking, and outdoor pollution, Environ. Health Perspect., 2003, 111, 1265-1272.

31. L. Rojas-Bracho, H. H. Suh, P. J. Catalano and P. Koutrakis, Personal exposures to particles and their relationships with personal activities for chronic obstructive pulmonary disease patients living in Boston, J Air Waste Manag Assoc., 2004, 54, 207-217.

32. E. Wigzell, M. Kendall and J. Nieuwenhuijsen, M. The spatial and temporal variation of particulate matter within the home, $J$ Expo Anal Environ Epidemiol, 2000, 10, 307-314.

33. Z. A. Nasir and I. Colbeck, Particulate pollution in different housing types in a UK suburban location, Sci. Total Environ., 2013, 445, 165-176.

34. C. O'Leary, Y. de Kluizenaar, P. Jacobs, W. Borsboom, I. Hall and B. Jones, Investigating measurements of fine particle (PM2.5) emissions from the cooking of meals and mitigating exposure using a cooker hood, Indoor Air, 2019, 29, 423-438. 
35. N. A. Mullen, J. Li, M. L. Russell, M. Spears, B. D. Less and B. C. Singer, Results of the California Healthy Homes Indoor Air Quality Study of 2011-2013: impact of natural gas appliances on air pollutant concentrations, Indoor Air, 2015, 26, 231-245.

36. C. O'Leary, S. Lofthouse and B. Jones Mitigating Occupant Exposure to PM2.5s Emitted by Cooking in High Occupancy Dwellings Using Natural Ventilation Strategies. 36th Air Infiltration and Ventilation Center Conference, Madrid, Spain. 2015, pp. 549-558.

37. K. L. Abdullahi, J. M. Delgado-Saborit and R. M. Harrison, Emissions and indoor concentrations of particulate matter and its specific chemical components from cooking: a review, Atmos. Environ., 2013, 71, 260-294.

38. G. J. Raw, S. K. D. Coward, V. M. Brown and D. R. Crump, Exposure to air pollutants in English homes, J. Exposure Anal. Environ. Epidemiol., 2004, 14(Suppl. 1), S85-S94.

39. C. Dimitroulopoulou, M. R. Ashmore, M. T. R. Hill, M. Byrne and R. Kinnersley, INDAIR: A probabilistic model of indoor air pollution in the U.K, Atmos. Environ., 2006, 40(33), 6362-6379.

40. C. Kornartit, R. S. Sokhi, A. Burton and K. Ravindra, Activity pattern and personal exposure to nitrogen dioxide in indoor and outdoor microenvironments, Environ. Int., 2010, 36, 36-45.

41. H. K. Lai, H. Ferrier, M. Kendall and I. Myers, Personal exposures and microenvironment concentrations of PM2.5, VOC, $\mathrm{NO} 2$ and $\mathrm{CO}$ in Oxford, UK, Atmos. Environ., 2004, 38, 6399-6410.

42. N. C. Jones, D. Mark, C. A. Thornton and R. M. Harrison, Indoor/outdoor relationships of particulate matter in domestic homes with roadside, urban and rural locations, Atmos. Environ., 2000, 34, 26032612.

43. K. A. BeruBe, K. J. Sexton, T. P. Jones and T. Moreno, The spatial and temporal variations in PM10 mass from six UK homes, Sci. Total Environ., 2004, 324, 41-53.

44. J. Taylor, C. Shrubsole, P. Symonds, I. Mackenzie and M. Davies, Application of an indoor air pollution metamodel to a spatially distributed housing stock, Sci. Total Environ., 2019, 667, 390-399.

45. HETAS, Defra's Cleaner Fuels Announcement Explained. Feb 25th 2020. https://www.hetas.co.uk/defras-cleaner-fuels-announcementexplained/.

46. L. Rokoff, P. Koutrakis, E. Garshick, M. R. Karagas, E. Oken, D. R. Gold and A. F. Fleisch, Wood Stove Pollution in the Developed World: A Case to Raise Awareness Among Pediatricians, Curr. Probl. Pediatr. Adolesc. Health Care, 2017, 47, 123-141.

47. Z. A. Nasir and I. Colbeck, Particulate pollution in different housing types in a UK suburban location, Sci. Total Environ., 2013, 445, 165-176.

48. R. M. Harrison, J. M. Delgado-Saborit, S. J. Baker, N. Aquilina, C. Meddings, S. Harrad, I. Matthews, S. Vardoulakis and H. R. AndersonMeasurement and Modelling of Exposure to Selected Air Toxics 
for Health Effects Studies and Verification bY Biomarkers, Health Research Institute, Boston, Research Report 143, 2009.

49. J. M. Delgado-Saborit, N. J. Aquilina, C. Meddings, S. Baker and R. M. Harrison, Relationship of personal exposure to volatile organic compounds to home, work and fixed site outdoor concentrations, Sci. Total Environ., 2011, 409, 478-488.

50. G. Bekö, C. G. Weschler, A. Wierzbicka, D. G. Karottki, J. Toftum, S. Loft and G. Clausen, Ultrafine Particles: Exposure and Source Apportionment in 56 Danish Homes, Environ. Sci. Technol., 2013, 47, 1024010248.

51. T. Hu, B. C. Singer and J. M. Logue Compilation of Published PM2.5 Emission Rates for Cooking, Candles and Incense for Use in Modelling of Exposures in Residences. August 2012. Ernest Orlando Lawrence Berkeley National Laboratory. LBNL Report Number LBNL-5890E. https://homes.lbl.gov/sites/all/files/brett_singer_-compilation_of_ published_pm_2.5_emission_rates_for_cooking_candles_and_ incense_for_the_use_in_modeling_of_exposeres_in_residences.pdf.

52. C. Dimitroulopoulou, E. Lucica, A. Johnson, M. R. Ashmore, I. Sakellaris, M. Stranger and E. Goelen, EPHECT I: European household survey on domestic use of consumer products and development of worst-case scenarios for daily use, Sci. Total Environ., 2015, 536, 880-889.

53. C. Dimitroulopoulou, M. Trantallidi, P. Carrer, G. Efthimiou and J. G. Bartzis, EPHECT II: Exposure assessment to household consumer products, Sci. Total Environ., 2015, 536, 890-902.

54. M. Trantallidi, C. Dimitroulopoulou, P. Wolkoff, S. Kephalopoulos and P. Carrer, EPHECT III: Health risk assessment of exposure to household consumer products, Sci. Total Environ., 2015, 536, 903-913.

55. A. W. Nørgaard, J. D. Kudal, V. Kofoed-Sørensen, I. K. Koponen and P. Wolkoff, Ozone-initiated VOC and particle emissions from a cleaning agent and an air freshener: risk assessment of acute airway effects, Environ. Int., 2014, 68, 209-218.

56. J. Bartzis, P. Wolkoff, M. Stranger, G. Efthimiou, E. I. Tolis, F. Maes, A. W. Nørgaard, G. Ventura, K. K. Kalimeri, E. Goelen, E. Fernandes and O. On, organic emissions testing from indoor consumer products' use, J. Hazard. Mater., 2015, 285, 37-45.

57. S. Batterman, J. Y. Chin, C. Jia, C. Godwin, E. Parker, T. Robins, P. Max and T. Lewis, Sources. Concentrations and Risks of naphthalene in indoor and outdoor air, Indoor Air, 2012, 22, 266-278.

58. L. Du, S. Batterman, C. Godwin, Z. Rowe and J. Y. Chin, Air exchange rates and migration of VOCs in basements and residences, Indoor Air, 2015, 25, 598-609.

59. C. M. Wang, B. Barratt, N. Carslaw, A. Doutsi, R. E. Dunmore, M. W. Ward and A. C. Lewis, Unexpectedly high concentrations of monoterpenes in a study of UK homes, Environ. Sci.: Processes Impacts, 2017, 19, 528-537. 
60. W. Sheehan, H. Brough, K. Makinson, C. Petty, G. Lack and W. Phipatanakul, Distribution of peanut protein in school and home environments of inner-city children, J. Allergy Clin. Immunol., 2017, 140, 1724-1726.

61. L. D. Knibbs, H. Congrong, C. Duchaine and L. Morawska, Vacuum Cleaner Emissions as a Source of Indoor Exposure to Airborne Particles and Bacteria, Environ. Sci. Technol., 2012, 46, 534-542.

62. O. Abbass, D. J. Sailor and E. T. Gall, Effectiveness of indoor plants for passive removal of indoor ozone, Build. Environ., 2017, 119, 62-70.

63. F. Haghighat and L. De Bellis, Material emission rates: Literature review, and the impact of indoor air temperature and relative humidity, Build Environ., 1998, 33, 261-277.

64. A. P. Jones, Indoor air quality and health, Atmos. Environ., 1999, 33, 4535-4564.

65. M. K. Owen, D. S. Ensor and L. E. Sparks, Airborne particle sizes and sources found in indoor air, Atmos. Environ., Part A, 1992, 26, 21492162.

66. C. J. Weschler and N. Carslaw, Indoor Chemistry, Environ. Sci. Technol., 2018, 52, 2419-2428.

67. S. M. Duncan, K. G. Sexton and B. J. Turpin, Oxygenated VOCs, aqueous chemistry, and potential impacts on residential indoor air composition, Indoor Air, 2018, 28, 198-212.

68. R. I. Adams, D. S. Lymperopoulou, P. K. Misztal, R. De Cassia Pessotti, S. W. Behie, Y. Tian, A. H. Goldstein, S. E. Lindow, W. W. Nazaroff, J. W. Taylor, M. F. Traxler and T. D. Bruns, Microbes and associated soluble and volatile chemicals on periodically wet household surfaces, Microbiome, 2017, 5, 128.

69. T. B. Manasfi, J. Coulomb and L. Boudenne, Occurrence, origin, and toxicity of disinfection by-products in chlorinated swimming pools: An overview, Int. J. Hyg. Environ. Health, 2017, 220, 591-603.

70. M. Kruza and N. Carslaw, How do breath and skin emissions impact indoor air chemistry?, Indoor Air, 2019, 29, 369-379.

71. Department for Education, 2018, BB101: Ventilation, thermal comfort and indoor air quality. Education and Skills Funding Agency. 2018. https://www.gov.uk/government/publications/building-bulletin-101ventilation-for-school-buildings.

72. X. Zhang, P. Wargocki and Z. Lian, Physiological responses during exposure to carbon dioxide and bioeffluents at levels typically occurring indoors, Indoor Air, 2017, 27, 65-77.

73. P. Wargocki, J. A. Porras-Salazar, S. Contreras-Espinoza and W. Bahnfleth, The relationships between classroom air quality and children's performance in school, Build. Environ., 2020, 173, 106749.

74. A. M. Karvonen, A. Hyvarinen, M. Roponen, M. Hoffman, M. Korppi, S. Remes, E. von Mutius, A. Nevalainen and J. Pekkanen, Confirmed moisture damage at home, respiratory symptoms and atopy in early life: a birth cohort study, Pediatrics, 2009, 124, e329-e338. 
75. B. Behbod, J. E. Sordillo, E. B. Hoffman, S. Datta, M. L. Muilenberg, J. A. Scott, G. L. Chew, T. A. Platts-Mills, J. Schwartz, H. Burge and D. R. Gold, Wheeze in infancy: protection associated with yeasts in house dust contrasts with increased risk associated with yeasts in indoor air and other fungal taxa, Allergy, 2013, 68, 1410-1418.

76. B. Behbod, B. Sordillo, J. E. Hoffman, E. B. Datta, S. Webb, T. E. Kwan and D. L. Kamel, JA. Asthma and allergy development: contrasting influences of yeasts and other fungal exposures, Clin. Exp. Allergy, 2015, 45, 154-163.

77. M. Lanari, F. Prinelli, F. Adorni, S. Di Santo, S. Vandini, M. Silvestri and M. Musicco, Risk factors for bronchiolitis hospitalization during the first year of life in a multi-center Italian birth cohort, Ital. J. Pediatr., 2015, 41, 40 .

78. P. F. Rosenbaum, J. A. Crawford, S. E. Anagnost, C. J. Wang, A. Hunt, R. D. Anbar, T. M. Hargrave, E. G. Hall, C. C. Liu and J. L. Abraham, Indoor airborne fungi and wheeze in the first year of life among a cohort of infants at risk for asthma, J. Exposure Sci. Environ. Epidemiol., 2010, 20, 503-515.

79. J. K. Ghosh, M. Wilhelm and B. Ritz, Effects of residential indoor air quality and household ventilation on preterm birth and term low birth weight in Los Angeles County, California, Am. J. Public Health, 2013, 103, 686-694.

80. U. Franck, A. Weller, S. W. Roder, G. Herberth, K. M. Junge, T. Kohajda, M. von Bergen, U. Rolle-Kampczyk, U. Diez, M. Borte and I. Lehmann, Prenatal VOC exposure and redecoration are related to wheezing in early infancy, Environ. Int., 2014, 73, 393-401.

81. U. Diez, M. Rehwagen, U. Rolle-Kampczyk, H. Wetzig, R. Schulz, M. Richter, I. Lehmann, M. Borte and O. Herbarth, Redecoration of apartments promotes obstructive bronchitis in atopy risk infantsresults of the LARS Study, Int. J. Hyg. Environ. Health, 2003, 206, 173-179.

82. M. Herr, J. Just, L. Nikasinovic, C. Foucault, A. M. Le Marec, J. P. Giordanella and I. Momas, Risk factors and characteristics of respiratory and allergic phenotypes in early childhood, J. Allergy Clin. Immunol., 2012, 130, 389-396.

83. C. Roda, I. Kousignian, C. Guihenneuc-Jouyaux, C. Dassonville, I. Nicolis, J. Just and I. Momas, Formaldehyde exposure and lower respiratory infections in infants: findings from the PARIS cohort study, Environ. Health Perspect., 2011, 119, 1653-1658.

84. C. Roda, I. Kousignian, A. Ramond and I. Momas, Indoor tetrachloroethylene levels and determinants in Paris dwellings, Environ. Res., 2013, 120, 1-6.

85. J. Henderson, A. Sherriff, A. Farrow and J. G. Ayres, Household chemicals, persistent wheezing and lung function: effect modification by atopy?, Eur. Respir. J., 2008, 31, 547-554. 
86. W. A. Jedrychowski, F. P. Perera, R. Majewska, D. Camman, J. D. Spengler, E. Mroz, L. Stigter, E. Flak and R. Jacek, Separate and joint effects of tranplacental and postnatal inhalatory exposure to polycyclic aromatic hydrocarbons: prospective birth cohort study on wheezing events, Pediatr. Pulmonol., 2014, 49, 162-172.

87. E. Diamanti-Kandarakis, J. P. Bourguignon, L. C. Giudice, R. Hauser, G. S. Prins, A. M. Soto, R. T. Zoeller and A. C. Gore, EndocrineDisrupting Chemicals: An Endocrine Society Scientific Statement, Endocr. Rev., 2009, 30, 293-342.

88. L. Wang, Z. Li, L. Jin, K. Li, Y. Yuan, Y. Fu, Y. Zhang, R. Ye and A. Ren, Indoor air pollution and neural tube defects: effect modification by maternal genes, Epidemiol., 2014, 25, 658-665.

89. E. Haraux, K. Braun, P. Buisson, E. Stephan-Blanchard, C. Devauchelle, J. Ricard, B. Boudailliez, P. Tourneux, R. Gouron and K. Chardon, Maternal exposure to domestic hair cosmetics and occupational endocrine disruptors is associated with a higher risk of hypospadias in the offspring, Int. J. Environ. Res. Public Health, 2017, 14, 27.

90. L. Y. Chen and C. Ho, Incense burning during pregnancy and birth weight and head circumference among term births: The Taiwan Birth Cohort Study, Environ. Health Perspect., 2016, 124, 1487-1492.

91. R. Nenna, R. Cutrera, A. Frassanito, C. Alessandroni, A. Nicolai, G. Cangiano, L. Petrarca, S. Arima, S. Caggiano, N. Ullmann, P. Papoff, E. Bonci, C. Moretti and F. Midulla, Modifiable risk factors associated with bronchiolitis, Ther. Adv Respir. Dis, 2017, 11, 393-401.

92. W. Jedrychowski, F. P. Perera, U. Maugeri, D. Mrozek-Budzyn, E. Mroz, E. Flak, S. Edwards, J. D. Spengler, R. Jacek, A. Sowa and A. Musia, Early wheezing phenotypes and severity of respiratory illness in very early childhood: study on intrauterine exposure to fine particle matter, Environ. Int., 2009, 35, 877-884.

93. C. C. Grant, D. Emery, T. Milne, G. Coster, C. B. Forrest, C. R. Wall, R. Scragg, R. Aickin, S. Crengle, A. Leversha, C. Tukuitonga and E. M. Robinson, Risk factors for community-acquired pneumonia in pre-school-aged children, J. Paediatr. Child Health, 2012, 48, 402-412.

94. L. Panico, B. Stuart, M. Bartley and Y. Kelly, Asthma trajectories in early childhood: identifying modifiable factors, PLoS One, 2014, 9, e111922.

95. H. Choi, S. Byrne, L. S. Larsen, T. Sigsqaard, P. S. Thorne, L. Larsson, A. Sebastian and C. G. Bornehag, Residential culturable fungi, (1-3, 16)- $\beta$-d-glucan, and ergosterol concentrations in dust are not associated with asthma, rhinitis, or eczema diagnoses in children, Indoor Air, 2014, 24, 158-170.

96. H. Sucharew, P. H. Ryan, D. Bernstein, P. Succop, G. K. Khurana Hershey, J. Lockey, M. Villareal, T. Reponen, S. Grinshpun and G. LeMasters, Exposure to traffic exhaust and night cough during early childhood: the CCAAPS birth cohort, Pediatr. Allergy Immunol., 2010, 21, 253-259. 
97. B. Behbod, B. Sordillo, J. E. Hoffman, E. B. Datta, S. Webb, T. E. Kwan and D. L. Kamel, JA. Asthma and allergy development: contrasting influences of yeasts and other fungal exposures, Clin. Exp. Allergy, 2015, 45, 154-163.

98. P. Carreiro-Martins, J. Viegas, A. L. Papoila, D. Aelenei, I. Caires, J. Araújo-Martins, J. Gaspar-Marques, M. M. Cano, A. S. Mendes, D. Virella, J. Rosado-Pinto, P. Leiria-Pinto, I. Annesi-Maesano and N. Neuparth, $\mathrm{CO}_{2}$ concentration in day care centres is related to wheezing in attending children, Eur. J. Pediatr., 2014, 173, 1041-1049.

99. P. Nafstad, J. J. Jaakkola, A. Skrondal and P. Magnus, Day care center characteristics and children's respiratory health, Indoor Air, 2005, 15, 69-75.

100. V. Fuentes-Leonarte, J. M. Tenías and F. Ballester, Levels of pollutants in indoor air and respiratory health in preschool children: a systematic review, Pediatr. Pulmonol., 2009, 44, 231-243.

101. N. N. Hansel, P. N. Breysse, M. C. McCormack, E. C. Matsui, J. Curtin-Brosnan and D. L. Williams, et al., A longitudinal study of indoor nitrogen dioxide levels and respiratory symptoms in inner-city children with asthma, Environ. Health Perspect., 2008, 116, 1428-1432.

102. J. H. Kwon, E. Kim, M. H. Chang, E. A. Park, Y. C. Hong and M. Ha, et al., Indoor total volatile organic compounds exposure at 6 months followed by atopic dermatitis at 3 years in children, Pediatr. Allergy Immunol., 2015, 26, 352-358.

103. K. W. Kim, K. Ahn, H. J. Yang, S. Lee, J. D. Park, W. K. Kim, J. T. Kim, H. H. Kim, Y. H. Rha, Y. M. Park, M. H. Sohn, J. W. Oh, H. R. Lee, D. H. Lim, J. T. Choung, M. Y. Han, E. Lee, H. Y. Kim, J. H. Seo, B. J. Kim, Y. A. Cho, K. H. Do, S. A. Kim, S. J. Jang, M. S. Lee, H. J. Kim, G. Y. Kwon, J. H. Park, J. Gwack, S. K. Youn, J. W. Kwon, B. Y. Jun, B. Y. Pyun and S. J. Hong, Humidifier disinfectant associated children's interstitial lung disease, Am. J. Respir. Crit. Care Med., 2014, 189, 48-56.

104. M. Callesen, G. Beko, C. J. Weschler, T. Sigsqaard, T. K. Jensen, G. Clausen, J. Toftum, L. A. Norberg and A. Høst, Associations between selected allergens, phthalates, nicotine, polycyclic aromatichydrocarbons, and bedroom ventilation and clinically confirmed asthma, rhinoconjunctivitis, and atopic dermatitis in preschool children, Indoor Air, 2014, 24, 136.

105. H. Choi, N. Schmidbauer, J. Sundell, M. Hasselgren, J. Spengler and C. G. Bornehag, Common household chemicals and the allergy risks in pre-school age children, PLoS One, 2010, 5, e13423.

106. C. Philippat, D. H. Bennett, P. Krakowiak, M. Rose, H. M. Hwang and I. Hertz-Picciotto, Phthalateconcentrations in house dust in relation to autism spectrum disorder and developmental delay in the CHildhood Autism Risks from Genetics and the Environment (CHARGE) study, Environ. Health, 2015, 14, 56.

107. B. Kolarik, Z. J. Andersen, T. Ibfelt, E. H. Engelund, E. Møller and E. V. Bräuner, Ventilation in day care centers and sick leave among nursery children, Indoor Air, 2016, 26, 157-167. 
108. P. Carreiro-Martins, J. Viegas, A. L. Papoila, D. Aelenei, I. Caires, J. Araújo-Martins, J. Gaspar-Marques, M. M. Cano, A. S. Mendes, D. Virella, J. Rosado-Pinto, P. Leiria-Pinto, I. Annesi-Maesano and N. Neuparth, $\mathrm{CO}_{2}$ concentration in day care centres is related to wheezing in attending children, Eur. J. Pediatr., 2014, 173, 1041-1049.

109. M. S. Perzanowski, G. L. Chew, A. Divjan, A. Johnson, I. F. Goldstein, R. S. Garfinkel, L. A. Hoepner, T. A. Platts-Mills, F. P. Perera and R. L. Miller, Cat ownership is a risk factor for the development of anticat IgE but not current wheeze at age 5 years in an inner-city cohort, J. Allergy Clin. Immunol., 2008, 121, 1047-1052.

110. J. D. Bufford, C. L. Reardon, Z. Li, K. A. Roberg, D. DaSilva, P. A. Eggleston, A. H. Liu, D. Milton, U. Alwis, R. Gangnon, R. F. Lemanske Jr and J. E. Gern, Effects of dog ownership in early childhood on immune development and atopic diseases, Clin. Exp. Allergy, 2008, 38, 1635-1643.

111. V. Abbing-Karahagopian, A. C. van der Gugten, C. K. van der Ent, C. Uiterwaal, M. de Jongh, M. Oldenwening, B. Brunekreef and U. Gehring, Effect of endotoxin and allergens on neonatal lung function and infancy respiratory symptoms and eczema, Pediatr. Allergy Immunol., 2012, 23, 448-455.

112. R. J. Bertelsen, K. C. Carlsen, K. H. Carlsen, B. Granum, G. Doekes, G. Håla, P. Mowinckel and M. Løvik, Childhood asthma and early life exposure to indoor allergens, endotoxin and beta (1,3)-glucans, Clin Exp Allergy, 2009, 40, 307-316.

113. A. Mendy, J. Gasana, E. R. Vieira, E. Forno, J. Patel, P. Kadam and G. Ramirez, Endotoxin exposure and childhood wheeze and asthma: a meta-analysis of observational studies, J. Asthma, 2011, 48, 685-693.

114. L. Shah, G. Mainelis, M. Ramagopal, K. Black and S. L. Shalat, Use of a robotic sampler (PIPER) for evaluation of particulate matter and eczema in pre-schoolers, Int. J. Environ. Res. Public Health, 2016, 13, 242.

115. M. Ramagopal, Z. Wang, K. Black, M. Hernandez, A. A. Stambler, O. H. Emoekpere, G. Mainelis and S. L. Shalat, Improved exposure characterization with robotic (PIPER) sampling and association with children's respiratory symptoms, asthma and eczema, J. Exposure Sci. Environ. Epidemiol., 2014, 24, 421-427.

116. M. C. McCormack, P. N. Breysse, E. C. Matsui, N. N. Hansel, D. Williams and J. Curtin-Brosnan, Center for Childhood Asthma in the Urban Environment. In-home particle concentrations and childhood asthma morbidity, Environ. Health Perspect., 2009, 117, 294-298.

117. H. O. Kim, J. H. Kim, S. I. Cho, B. Y. Chung, I. S. Ahn, C. H. Lee and C. W. Park, Improvement of atopic dermatitis severity after reducing indoor air pollutants, Ann. Dermatol., 2013, 25, 292-297.

118. L. Panico, B. Stuart, M. Bartley and Y. Kelly, Asthma trajectories in early childhood: identifying modifiable factors, PLoS One, 2014, 9, e111922. 
119. J. A. Castro-Rodriguez, E. Forno, C. E. Rodriguez-Martinez and J. C. Celedón, Risk and Protective Factors for Childhood Asthma: What Is the Evidence?, J. Allergy Clin. Immunol. Pract., 2016, 4, 1111-1122.

120. A. Bjerg and E. Rönmark, Asthma in school age: prevalence and risk factors by time and by age, Clin. Respir J, 2008, 2, 123-126.

121. A. Bjerg, L. Hedman, M. Perzanowski, G. Wennergren, B. Lundbäck and E. Rönmark, Decreased importance of environmental risk factors for childhood asthma from 1996 to 2006, Clin. Exp Allergy, 2015, 45, 146153.

122. F. Cibella, G. Cuttitta, S. La Grutta, M. R. Melis, M. L. Lospalluti, C. G. Uasuf, S. Bucchieri and G. Viegi, Proportional Venn diagram and determinants of allergic respiratory diseases in Italian adolescents, Pediatr. Allergy Immunol., 2011, 22, 60-68.

123. L. D. Knibbs, S. Woldeyohannes, G. B. Marks and C. T. Cowie, Damp housing, gas stoves, and the burden of childhood asthma in Australia, Med. J. Aust., 2018, 208, 299-302.

124. A. Borass-Santos, J. H. Jacobs, M. Taubel, U. Haverinen-Shaughnessy, E. Krop, K. Huttunen, M. R. Hirvonen, J. Pekkanen, D. J. Heederik, J. P. Zock and A. Hyvärinen, Dampness and mould in schools and respiratory symptoms in children: the HITEA study, Occup. Environ. Med., 2013, 70, 681-687.

125. H. W. Meyer, P. Suadicani, P. A. Nielsen, T. Sigsgaard and F. Gyntelberg, Moulds in floor dust - a particular problem in mechanically ventilated rooms? A study of adolescent schoolboys under the Danish moulds in buildings program, Scand. J. Work, Environ. Health, 2011, 37, 332-340.

126. M. Simoni, G. H. Cai, D. Norback, I. Annesi-Maesano, F. Lavaud, T. Sigsgaard, G. Wieslander, W. Nystad, M. Canciani, G. Viegi and P. Sestini, Total viable molds and fungal DNA in classrooms and association with respiratory health and pulmonary function of European schoolchildren, Pediatr Allergy Immunol, 2011, 22, 843-852.

127. I. Stelmach, Ł. Cichalewski, P. Majak, K. Smejda, D. Podlecka, J. Jerzyńska and W. Stelmach, School environmental factors are predictive for exercise-induced symptoms in children, Respir. Med., 2016, 112, 25-30.

128. T. Reponen, S. Vesper, L. Levin, E. Johansson, P. Ryan and J. Burkle, High environmental relative moldiness index during infancy as a predictor of asthma at 7 years of age, Ann. Allergy, Asthma, Immunol., 2011, 107, 120-126.

129. J. Hsu, X. Qin, S. F. Beavers and M. C. Mirabelli, Asthma related school absenteeism, morbidity and modifiable factors, Am J Prev Med, 2016, 51, 23-32.

130. C. M. Tiesler, E. Thiering, C. Tischer, I. Lehmann, B. Schaaf, A. von Berg and J. Heinrich, Exposure to visible mould or dampness at home and sleep problems in children: Results from the LISAplus study, Environ. Res., 2015, 137, 357-363. 
131. E. Simons, S. A. Hwang, E. F. Fitzgerald, C. Kielb and S. Lin, The impact of school building conditions on student absenteeism in upstate New York, Am. J. Public Health, 2010, 100, 1679-1686.

132. S. Rive, M. Hulin, N. Baiz, Y. Hassani, H. Kigniniman and Y. Toloba, Urinary S-PMA related to indoor benzene and asthma in children, Inhalation Toxicol., 2013, 25, 373-382.

133. J. Madureira, I. Paciência, E. Ramos, H. Barros, C. Pereira, J. P. Teixeira and E. O. Fernandes, Children's health and indoor air quality in primary schools and homes in Portugal-study design, J. Toxicol. Environ. Health, 2015, 78, 915-930.

134. R. Singleton, A. J. Salkoski, L. Bulkow, C. Fish, J. Dobson, L. Albertson, J. Skarada, T. Kovesi, C. McDonald, T. W. Hennessy and T. Ritter, Housing characteristics and indoor air quality in households of Alaska Native children with chronic lung conditions, Indoor Air, 2017, 27, 478486.

135. S. Cakmak, R. E. Dales, L. Liu, L. M. Kauri, C. L. Lemieux, C. Hebbern and J. Zhu, Residential exposure to volatile organic compounds and lung function: results from a population-based cross-sectional survey, Environ. Pollut., 2014, 194, 145-151.

136. M. Hulin, D. Caillaud and Annesi-Maesano, Indoor air pollution and childhood asthma: variations between urban and rural areas, Indoor Air, 2010, 20, 502-514.

137. I. Annesi-Maesano, M. Hulin, F. Lavaud, C. Raherison, C. Kopferschmitt, F. de Blay, D. A. Charpin and C. Denis, Poor air quality in classrooms related to asthma and rhinitis in primary schoolchildren of the French 6 cities study, Thorax, 2012, 67, 682-688.

138. Y. Ait Bamai, A. Araki, T. Kawai, T. Tsuboi, I. Saito, E. Yoshioka, A. Kanazawa, S. Tajima, C. Shi, A. Tamakoshi and R. Kishi, Associations of phthalate concentrations in floor dust and multi-surface dust with the interior materials in Japanese dwellings, Sci. Total Environ., 2014, 15, 468-469.

139. K. Belanger, T. R. Holford, J. F. Gent, M. E. Hill, J. M. Kezik and B. P. Leaderer, Household levels of nitrogen dioxide and pediatric asthma severity, Epidemiol., 2013, 24, 320-330.

140. M. Mortamais, J. Pujol, B. L. van Drooge, D. Macià, G. Martínez-Vilavella, C. Reynes, R. Sabatier, I. Rivas, J. Grimalt, J. Forns, M. Alvarez-Pedrerol, X. Querol and J. Sunyer, Effect of exposure to polycyclic aromatic hydrocarbons on basal ganglia and attentiondeficit hyperactivity disorder symptoms in primary school children, Environ. Int., 2017, 105, 12-19.

141. X. Xu, W. N. Nembhard, H. Kan, A. Becker and E. O. Talbott, Residential pesticide use is associated with children's respiratory symptoms, J. Occup. Environ. Med., 2012, 54, 1281-1287.

142. H. P. Hutter, D. Haluza, K. Piegler, P. Hohenblum, M. Fröhlich, S. Scharf, M. Uhl, B. Damberger, P. Tappler, M. Kundi, P. Wallner and H. Moshammer, Semivolatile compounds in schools and their 
influence on cognitive performance of children, Int J Occup. Med Environ Health, 2013, 26, 628-635.

143. F. A. Rabito, J. Carlson, E. W. Holt, S. Iqbal and M. A. James, Cockroach exposure independent of sensitization status and association with hospitalizations for asthma in inner-city children, Ann. Allergy, Asthma, Immunol., 2011, 106, 103-109.

144. J. A. Pongracic, C. M. Visness, R. S. Gruchalla, R. Evans and H. E. Mitchell, Effect of mouse allergen and rodent environmental intervention on asthma in inner-city children, Ann. Allergy, Asthma, Immunol., 2008, 101, 35-41.

145. W. Phipatanakul, J. C. Celedon, E. B. Hoffman, H. Abdulkerim, L. M. Ryan and D. R. Gold, Mouse allergen exposure, wheeze and atopy in the first seven years of life, Allergy, 2008, 63, 1512-1518.

146. G. T. O'Connor, S. V. Lynch, G. R. Bloomberg, M. Kattan, R. A. Wood and P. J. Gergen, Early-life home environment and risk of asthma among inner-city children, J. Allergy Clin. Immunol., 2018, 141, 1468-1475.

147. K. D. Lu, P. N. Breysse, G. B. Diette, J. Curtin-Brosnan, C. Aloe and D. L. Williams, Being overweight increases susceptibility to indoor pollutants among urban children with asthma, J. Allergy Clin. Immunol., 2013, 131, 1017-1023.

148. W. A. Jedrychowski, F. P. Perera, J. D. Spengler, E. Mroz, L. Stigter, E. Flak, R. Majewska, M. Klimaszewska-Rembiasz and R. Jacek, Intrauterine exposure to fine particulate matter as a risk factor for increased susceptibility to acute broncho-pulmonary infections in early childhood, Int. J. Hyg. Environ. Health, 2013, 216, 395-401.

149. K. Isiugo, R. Jandarov, J. Cox, P. Ryan, N. Newman, S. A. Grinshpun, R. Indugula, S. Vesper and T. Reponen, Indoor particulate matter and lung function in children, Sci. Total Environ., 2019, 663, 408-417.

150. M. Simoni, I. Annesi-Maesano, T. Sigsgaard, D. Norback, G. Wieslander, W. Nystad, M. Canciani, P. Sestini and G. Viegi, School air quality related to dry cough, rhinitis and nasal patency in children, Eur. Respir. J., 2010, 35, 742-749.

151. Y. H. Mi, D. Norback, J. Tao, Y. L. Mi and M. Ferm, Current asthma and respiratory symptoms among pupils in Shanghai, China: influence of building ventilation, nitrogen dioxide, ozone, and formaldehyde in classrooms, Indoor Air, 2006, 16, 454-456.

152. D. G. Shendell, R. Prill, W. J. Fisk, M. G. Apte, D. Blake and D. Faulkner, Associations between classroom $\mathrm{CO} 2$ concentrations and student attendance in Washington and Idaho, Indoor Air, 2004, 14, 333-341.

153. S. Gaihre, S. Semple, J. Miller, S. Fielding and S. Turner, Classroom carbon dioxide concentration, school attendance, and educational attainment, J. Sch. Health, 2014, 84, 569-574.

154. M. J. Mendell, E. A. Eliseeva, M. M. Davies, M. Spears, A. Lobscheid, W. J. Fisk and M. G. Apte, Association of classroom ventilation with reduced illness absence: a prospective study in California elementary schools, Indoor Air, 2013, 23, 515-528. 
155. D. A. Coley, R. Greeves and B. K. Saxby, The effect of low ventilation rates on the cognitive function of a primary school class, Int. J. Vent, 2007, 6, 107-112.

156. A. Ferreira and M. Cardoso, Indoor air quality and health in schools, J. Bras. Pneumol., 2014, 40, 259-268.

157. W. J. Fisk, The ventilation problem in schools: literature review, Indoor Air, 2017, 27, 1039-1051.

158. T. Barret, $\mathrm{NO}_{2}$ falls 'significantly' in London during lockdown, but PM rises. Air Quality News, https://airqualitynews.com/2020/05/07/studyno2-falls-significantly-since-lockdown-in-london-but-pm-rises/.

159. H. Salonen, T. Salthammer and L. Morawska, Human exposure to ozone in school and office indoor environments, Environ. Int., 2018, 119, 503-514.

160. C. J. Weschler and N. Carslaw, Indoor Chemistry, Invited feature article for, Environ. Sci. Technol., 2018, 52, 2419-2428.

161. N. Carslaw, T. Mota, M. E. Jenkin, M. H. Barley and G. McFiggans, A significant role for nitrate and peroxide groups on indoor secondary organic aerosol, Environ. Sci. Technol., 2012, 46, 9290-9298.

162. L. Morawska and J. Cao, Airborne transmission of SARS-CoV-2: The world should face the reality, Environ. Int., 2020, 139, 105730.

163. G. Correia, L. Rodrigues, M. Gameiro da Silva and T. Gonçalves, Airborne route and bad use of ventilation systems as non-negligible factors in SARS-CoV-2 transmission, Med. Hypotheses, 2020, 141, 109781.

164. Y. Li, G. M. Leung, J. W. Tang, X. Yang, C. Y. Chao, J. Z. Lin, J. W. Lu, P. V. Nielsen, J. Niu, H. Qian, A. C. Sleigh, H. J. Su, J. Sundell, T. W. Wong and P. L. Yuen, Role of ventilation in airborne transmission of infectious agents in the built environment - a multidisciplinary systematic review, Indoor Air, 2007, 17, 2-18.

165. F. Dutheil, J. S. Baker and V. Navel, COVID-19 as a factor influencing air pollution?, Environ. Pollut., 2020, 263(Pt A), 114466.

166. E. Conticini, B. Frediani and D. Caro, Can atmospheric pollution be considered a co-factor in extremely high level of SARS-CoV-2 lethality in Northern Italy?, Environ. Pollut., 2020, 114465.

167. Y. Ogen, Assessing nitrogen dioxide $\left(\mathrm{NO}_{2}\right)$ levels as a contributing factor to coronavirus (COVID-19) fatality, Sci. Total Environ., 2020, 726, 138605.

168. L. Dietz, P. F. Horve, D. A. Coil, M. Fretz, J. A. Eisen, Van Den and K. Wymelenberg, 2019 Novel Coronavirus (COVID-19) Pandemic: Built Environment Considerations to Reduce Transmission, mSystems, 2020, 5, pii: e00245-20.

169. P. F. Horve, S. Lloyd, G. A. Mhuireach, L. Dietz, M. Fretz, G. MacCrone, K. Van Den Wymelenberg and S. L. Ishaq, Building upon current knowledge and techniques of indoor microbiology to construct the next era of theory into microorganisms, health, and the built environment, J. Exposure Sci. Environ. Epidemiol., 2020, 30, 219-235. 
170. Overcrowded housing (England). House of Commons Library. Briefing Paper Number 1013, 31 March 2020. https://commonslibrary. parliament.uk/research-briefings/sn01013/.

171. J. F. Ludvigsson, Systematic review of COVID-19 in children shows milder cases and a better prognosis than adults, Acta Paediatr., 2020, DOI: 10.1111/apa.15270.

172. S. Riphagen, X. Gomez, C. Gonzalez-Martinez, N. Wilkinson and P. Theocharis, Hyperinflammatory shock in children during COVID-19 pandemic, Lancet, 2020, DOI: 10.1016/S0140-6736(20)31094-1.

173. A. A. Kelvin and S. Halperin, COVID-19 in children: the link in the transmission chain, Lancet Infect. Dis., 2020, DOI: 10.1016/S14733099(20)30236-X. 